NBSIR 79-1931

\title{
Fire Experiments and Flash Point Criteria for Solar Heat Transfer Liquids
}

B. T. Lee and W. D. Walton

Center for Fire Research National Engineering Laboratory National Bureau of Standards U.S. Department of Commerce Washington, D.C. 20234

November 1979

Final Report

Prepared for

Department of Energy

ashington, D.C. 20545

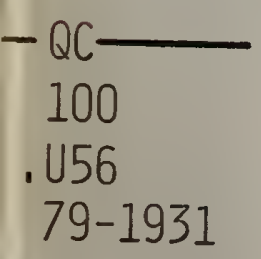





\section{FIRE EXPERIMENTS AND FLASH POINT CRITERIA FOR SOLAR HEAT TRANSFER LIQUIDS}

B. T. Lee and W. D. Walton

Center for Fire Research

National Engineering Laboratory

National Bureau of Standards

U.S. Department of Commerce

Washington, D.C. 20234

November 1979

Final Report

Prepared for

Department of Energy

Washington, D.C. 20545

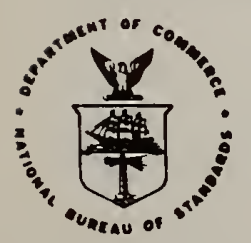

U.S. DEPARTMENT OF COMMERCE

Luther H. Hodges, Jr., Under Secretary

Jordan J. Baruch, Assistant Secretary for Science and Technology

NATIONAL BUREAU OF STANDARDS, Ernest Ambler, Director 


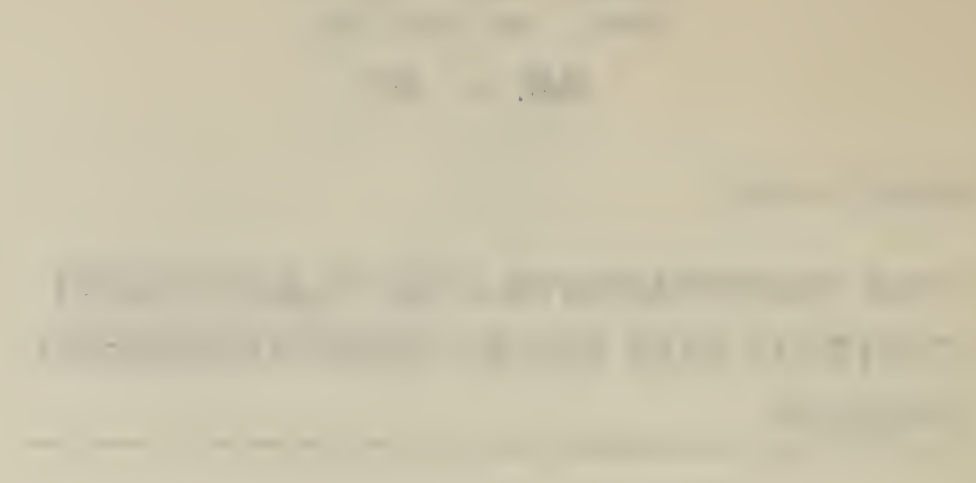

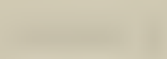

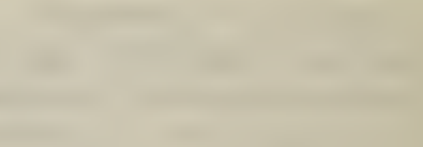

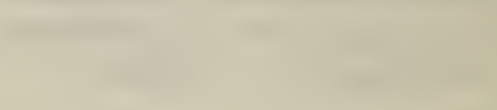


TABLE OF CONTENTS

Page

LIST OF TABLES . . . . . . . . . . . . . . . . . . . . . iv

LIST OF FIGURES . . . . . . . . . . . . . . . . . . . . iv

Abstract . . . . . . . . . . . . . . . . . . . 1

1. INTRODUCTION . . . . . . . . . . . . . . . . 1

2. EXPERIMENTAL ARRANGEMENT . . . . . . . . . . . . . 6

2.1 Flash Point . . . . . . . . . . . . . . 6

2.2 Room Fire Tests ............... . . 6

2.2.1 Liquid Spill ................ 7

2.2.2 Flowing Liquid Leak .............. . 8

2.3 Other Fire Tests.................. . . 9

2.3.1 Spray Leak .................. 9

2.3.2 Liquid Soaked Insulation . . . . . . . . . 9

3. RESULTS AND DISCUSSION . . . . . . . . . . . . . . 9

3.1 Flash Point . . . . . . . . . . . . . . . 9

3.2 Liquid Spill . . . . . . . . . . . . . . . . 10

3.3 Flowing Liquid Leak . . . . . . . . . . . . . . . 11

3.4 Spray Leak . . . . . . . . . . . . . . . . . 12

3.5 Liquid Soaked Insulation . . . . . . . . . . . 12

4. SUMMARY OF EXPERIMENTAL FINDINGS . . . . . . . . . . . . 13

5. DEVELOPMENT OF CRITERIA . . . . . . . . . . . . . . . 13

6. PROPOSED CRITERIA . . . . . . . . . . . . . . . 15

7. ACKNOWLEDGMENTS . . . . . . . . . . . . . . . . 17

8. REFERENCES . . . . . . . . . . . . . . . . . 17 
Table 1. Flash point and fire points for some common solar heat transfer liquids .............. 19

Table 2. Experimental conditions for the five fluid spill cases 20

Table 3. Solar heat transfer fluids used in spray tests . . . 21

Table 4. Case A fluid spill fires . . . . . . . . . . 22

Table 5. Case B fluid spill fires.............. 23

Table 6. Case C fluid spill fires ............ . 24

Table 7. Case D fluid spill fires............ . 25

Table 8. Case E fluid spill fires............. 26

Table 9. Fluid spill fires - ethylene glycol and ethylene glycol-water mixtures . . . . . . . . . . 27

Table 10. Flowing fluid fire test (pilot flame only) - light hydrocarbon oil . . . . . . . . . . . . 28

Table 11. Flowing fluid fire test (pilot flame only) - extractednaphthenic oil ............... 29

Table 12. Flowing fluid fire test (pilot flame only) polyalkylene glycol . . . . . . . . . . 30

Table 13. Flowing fluid fire tests (pilot flame only) - ethylene glycol and glycol-water mixtures . . . . . . . . 31

Table 14. Flammability of fluid soaked insulation . . . . . . 32

\section{LIST OF FIGURES}

Figure 1. Active solar energy system . . . . . . . . . . . 33

Figure 2. Reduced scale room fire test . . . . . . . . . . 34

Figure 3. Fluid spill test pan with spiral gas burner in place . 34

Figure 4. Spray test setup . . . . . . . . . . . . . 35

Figure 5. Correlation with flash point temperature . . . . . 36 


\title{
FIRE EXPERIMENTS AND FLASH POINT CRITERIA FOR SOLAR HEAT TRANSFER LIQUIDS
}

B. T. Lee and W. D. Walton

\begin{abstract}
To help provide a rational basis for developing flammability criteria for heat transfer fluids used in solar energy collection systems, fire tests were performed using simulated accident scenarios involving spills, flowing leaks, spray leaks, and soaked insulation. These experiments indicated that the flash point temperatures, as measured with the Pensky-Martens closed cup apparatus, are close to the minimum temperatures at which pools of the fluids will support a flame when they are exposed to a small pilot igniting flame in a room. The heat release from moderate sized burning pools of these liquids is sufficlent to cause flashover in a room.
\end{abstract}

Interim flash point criteria of at least $28 \mathrm{deg} C$ (50 deg F) greater than the maximum operating temperature and not more than $111 \mathrm{deg} C$ (200 deg F) below the maximum no-flow temperature are proposed to reduce the risk of fire in the use of solar heat transfer liquids.

Key words: Fire prevention; fire tests; flammability; flash point; heat transfer fluids; Insulation; leakage; solar collectors; solar energy.

\section{INTRODUCTION}

As the nation becomes more concerned with energy conservation, the use of solar heating and cooling systems is becoming increasingly popular. Although solar heating is an important alternate form of energy, there is no adequate standard addressing the safe use of combustible heat transfer liquids in such systems for residentlal occupancles. Safety standards are avallable for the general use and storage of flammable and combustible liquids, including conventional heating fuels; but these standards do not consider the particular problems of heat transfer liquids in solar heating and cooling systems. Solar heating and cooling is still basically a new technology even though systems have been operational for some time. Since there has been no substantial research in this area, performance criterla for flammable and combustible solar heat transfer liquids have been difficult to set.

The terms defined below are used throughout the report, and pertain to solar heating and cooling systems, to combustible and flammable liquids and to fire phenomena. 
Ambient temperature - The average air temperature in the testing facility. During the tests reported here the ambient temperature was $22 \pm 3^{\circ} \mathrm{C}\left(72 \pm 5^{\circ} \mathrm{F}\right)$.

Autoignition temperature - Temperature to which a closed or nearly closed container must be heated in order that the liquid in question, when introduced into the container, will ignite and burn in the absence of a flame or glowing heat source. Time lags of a minute or more are frequently involved. The standard test method for autoignition temperature of petroleum products is described in ASTM D 2155, Autoignition Temperature of Petroleum Products [1] ${ }^{1}$.

Collector - The assembly used for absorbing solar radiation, converting it into useful thermal energy and transferring the thermal energy to a heat transfer fluid.

Combustible liquid - Any liquid having a flash point at or above $37.8^{\circ} \mathrm{C}\left(100^{\circ} \mathrm{F}\right)[2]$.

Fire point - The lowest temperature of a liquid in an open container at which vapors are evolved fast enough to support continuous combustion. The fire point is higher than the flash point [1].

Flammable liquid - Any liquid having a flash point below $37.8^{\circ} \mathrm{C}$ $\left(100^{\circ} \mathrm{F}\right)$ [2].

Flash point - The minimum temperature of a liquid at which sufficient vapor is given off to form an ignitable mixture with the air near its surface. The flash point is determined by a specified test procedure and apparatus [1]. Four standard methods are available for measuring flash point:

(1) Pensky-Martens closed cup ASTM D 93

(2) Cleveland open cup ASTM D 92

(3) Tag closed cup ASTM D 56

(4) Tag open cup ASTM D 1310

Flash Point Range

The method used depends on the flash point range and viscosity of the liquid and whether an open or closed cup test is appropriate or specified. NFPA No. 321, Basic Classification of Flammable and Combustible Liquids [2], specifies closed cup only. Open cup flash points are sometimes used in grading flammable liquids in transportation [1]. It should be noted that the flash point varies with the pressure and oxygen content of the atmosphere, with the purity of the product being tested, with the method of test, and with the skill of the operator running the test [1].

${ }^{1}$ Numbers in brackets refer to the literature references listed at the end of this report. 
Flameover - The fire condition in which flames reach out of the doorway of the fire room.

Flashover - The fire condition in which the thermal radiation level in a room becomes high enough to ignite remote combustible materials such as newspaper and upholstered furniture in the lower half of the room.

Heat transfer liquid - The operating or thermal storage liquid used to transfer heat from the collector to the storage or heat exchanger system. Typically, it consists of water or other liquid base and all additives at the concentration used under operating conditions.

Insolation - The incident solar energy, often expressed as heat flow rate per unit horizontal surface.

No-flow temperature - The average temperature of the heat transfer fluid in the collector when the fluid is not moving. The design maximum no-flow temperature is the liquid temperature under design conditions of insolation and outdoor air temperature which cause the highest collector temperature at a given site. Typical no-flow temperatures for residential heating systems vary from $120^{\circ} \mathrm{C}\left(248^{\circ} \mathrm{F}\right)$ to $230^{\circ} \mathrm{C}\left(446^{\circ} \mathrm{F}\right)$ and from $175^{\circ} \mathrm{C}\left(347^{\circ} \mathrm{F}\right)$ to $370^{\circ} \mathrm{C}\left(698^{\circ} \mathrm{F}\right)$ for cooling systems.

Operating temperature (Flow temperature) - The average temperature of the heat transfer liquid in the solar heating system under normal operating conditions; typically, this ranges from $20^{\circ} \mathrm{C}$ $\left(68^{\circ} \mathrm{F}\right)$ to $90^{\circ} \mathrm{C}\left(194^{\circ} \mathrm{F}\right)$ for residential heating systems and from $90^{\circ} \mathrm{C}\left(194^{\circ} \mathrm{F}\right)$ to $150^{\circ} \mathrm{C}\left(302^{\circ} \mathrm{F}\right)$ for cooling systems. The design maximum operating temperature is the liquid temperature measured at the collector outlet, or manifold, under the conditions of insolation and outdoor air temperature which cause the highest operating temperature at a given site. For systems involving multiple fluid loops this temperature is taken to be the maximum attained in any loop under the conditions stated above.

Solar energy system, active - A system which may include collectors, thermal storage heat transfer fluid and load, and which utilizes solar energy for heating and/or cooling and in which all fluid flows are by forced means (pumps or fans) [7].

Solar energy system, hybrid - A system which may include collectors, thermal storage, heat transfer and load, and which utilizes solar energy or environmental energy sinks for heating and/or cooling and in which at least one energy flow is by forced means and at least one is by natural means [7].

Solar energy system, passive - A system which may include collector, thermal storage, heat transfer fluid and load, and which utilizes solar energy and fluid or environmental energy sinks for heating 
and/or cooling and in which all energy flows are by natural means (conduction, convection, radiation, or evaporation) [7].

It is difficult to characterize a "typical" solar energy system because of variations in factors such as climate, system design and efficiency, size of the building to be served, and the percent of the total energy load the solar system is expected to provide. For a single family residence the solar system may be designed to provide domestic hot water, space heating or both. Figure 1 shows a representative active system configuration. A domestic hot water system would generally contain from 4 to 11 square meters (40 to $120 \mathrm{ft}^{2}$ ) of collector area and a space heating system from 9 to 74 square meters ( 100 to $800 \mathrm{ft}^{2}$ ) of collector area. An average collector has an area of 2 square meters $\left(20 \mathrm{ft}^{2}\right)$ and contains approximately 2 liters $(1 / 2 \mathrm{gal})$ of heat transfer fluid. In terms of overall system fluid capacity including collectors, piping and heat exchanges a hot water system would typically contain 19 to 38 liters ( 5 to 10 gal) of heat transfer fluid and a space heating system 38 to 189 liters (10 to $50 \mathrm{gal}$ ) of fluid. In addition to the heat transfer liquid the solar energy system may contain a thermal storage fluid which is typically water. The amount of thermal storage fluid may range into the thousands of liters if the storage is expected to carry the heating load for an extended period of time during which the system can collect little or no solar energy.

The fire hazard of a particular process or occupancy may be evaluated by the development of potential fire scenarios that approximate actual use conditions. Scenarios are usually based on an evaluation of statistical data on fire frequency and cause if such data are available. If an adequate data base does not exist, the scenarios must be based on judgment and the limited data that are available. In the present case, a suitable data base is not available for fire occurring in conjunction with solar heating systems. Therefore, the development of fire occurrence scenarios and the determination of the protection required are based on our experience and judgment. This technique has been chosen in an attempt to anticipate potential fire problems and to suggest an acceptable level of safety.

The examination of fire occurrence scenarios pertains primarily to active solar energy systems and the active portion of hybrid systems since these are the systems which normally contain combustible heat transfer liquids. Ideally solar heating and cooling systems should not leak under normal operation; however, experience with existing solar installations has indicated a substantial number of leaks will occur. Thus, in the scenarios selected, a leak in the collector piping system results in the discharge of the heat transfer liquid at a temperature greater than that of the surrounding air. If the liquid is a flammable or combustible liquid and the temperature is sufficiently high, flammable vapors will be produced which may be ignited by an available ignition source. There are several important variations, such as the location and nature of the fluid leak or discharge and whether the system is in an operating or no-flow mode. Specifically these scenarios could involve: 
(1) a pipe break which results in a substantial leak spilling on the floor and forming a liquid pool, or a drip from a loose pipe connection, faulty pump packing, partially open drain, etc., which over a period of time could result in a pool of the liquid on the floor, (2) a substantial leak occurring in the piping network away from the collector area while the systen is in the no-flow condition, where one would expect the discharge of some liquid, which was contained in the pipes at close to the operating temperature, followed by hotter liquid from the collectors, and (3) a small leak under high pressure causing a spray or mist. If the spray should occur in the attic space, thermal insulation might be soaked with the fluid, posing an additional potential fire problem.

Incorporated in the evaluation of each scenario is the presence of an ignition source. There is a high probability that a non-hostile ignition source will exist in a building at the time of a leak. A nonhostile ignition source is one associated with the normal operation of appliances or normal activities. This would include pilot flames or burners in heating appliances, electric resistance heating elements, sparks from electrical appliances and switches, fires in fireplaces and stoves, smoking materials, etc. An incidental fire may also occur; this is one which is not a normal occurrence and will not result, by itself, in total fire involvement of a room or building. Nevertheless it is desirable that leaks and spills of the heat transfer fluid adjacent to or in the vicinity of such fires would not easily contribute to the fire growth.

In this study no attempt has been made to provide for the hazards resulting from welding, cutting, soldering or brazing pipes and other components which contain combustible liquids. Standard methods for reducing these hazards are available and are the responsibility of the individuals engaged in such operations. In addition, the problem of intentionally set fires or relatively unusual occurrences, such as lightning strikes, have not been addressed.

The objective of this project is to provide an experimental basis for specifying flammability test standards for the heat transfer liquids used in solar heating systems and recommend such standards.

The closed cup flash point was selected for the presentation and correlation of the data. The open cup flash point and fire point could also be used for this purpose. The autoignition temperature is a property of a fluid that can be measured, but has not been judged useful as a measure of the fire hazard of liquids for solar heating and cooling systems. The autoignition temperature is most useful for determining the ignition susceptibility of liquids in contact with hot surfaces in the absence of a pilot ignition source. Some liquids with very high autoignition temperatures produce flammable vapors below a temperature of $0^{\circ} \mathrm{C}$. These vapors may travel considerable distances and are easily ignited by a spark or flame.

Other factors are important in evaluating the overall performance of a flammable or combustible 1iquid. These include the flammable 
limits, rate of evaporation, density and rate of diffusion of the vapors, specific gravity, boiling point, water solubility, and effective heat of combustion. Although these factors are important for evaluating explosion Dotential, burning rate, extinguishability and a variety of other conditions, the susceptibility to ignition is the most important property for evaluating solar heat transfer fluids.

\section{EXPERIMENTAL ARRANGEMENT}

As previously described, several fire scenarios involving leaks and spills of these heat transfer fluids were considered for the fire tests. The accident scenarios employed can be categorized briefly as follows: (1) floor spills of these fluids in a room in combination with an incidental fire nearby or with a flame in contact with the fluid, (2) flowing fluid leaks and liquid spray leaks in the presence of pilot flames in a room but in the absence of an incidental fire, and (3) liquid spray leaks on attic insulation with subsequent non-hostile flame ignition. With a floor spill the hot fluid is heated by the fire and cooled by contact with the floor. As the fluid continues to sp111, the heat losses to the floor would decrease and the fluid could, in some cases, remain close to the flash point temperature. Flames in contact with the fluid might then spread across it and produce heat release rates sufficient to produce flashover of the room. The floor spill scenarios were studied in detail to examine the role of flash point in room fire growth under a variety of fire exposure conditions. A flowing leak could involve a hot fluid at the operating temperature discharging through a break in the system ontio a dry ambient temperature surface. If the system were in the no-flow mode, this discharge could be followed by a hotter fluid originally at the stagnation temperature in the collector. Discharges of the hot liquid onto a dry ambient temperature surface and into a pool of the same liquid were both studied. Replicate fire tests were not performed due to cost and time limitations and the large number of fire scenarios examined.

\subsection{Flash Point}

The flash points of ten commonly used solar heat transfer liquids shown in table 1 were measured with the Pensky-Martens closed cup test [3] and for comparison the flash points and fire points were also measured with the Cleveland open cup test [4]. Eight of these fluids, indicated in the table, were selected for the research study. The alkylated aromatic and diphenyl-diphenyl oxide were excluded from further study as they were considered too toxic to handle safely in the avallable fire test facility. In addition, a light hydrocarbon oil, also shown in the table, having low flash point was included in the investigation for comparison purposes and to extend the flash point range.

\subsection{Room Fire Tests}

In order to assess the potential fire hazard introduced by the spilled or flowing liquid, it is appropriate to burn it in a room where 
the burning rate of the liquid w1ll be affected by radiation feedback from the flames of an existing fire or from the high temperatures in the room. A fire in a room raises the temperature of the air and the temperature of the room surfaces. This causes a rise in the thermal radiation levels in the room resulting in an increase in the burning rate of the liquid. If there is a sufficient increase in the rate of combustion, the room will flashover and the integrity of the building will be threatened.

Three full-scale room fire tests were performed, and these involved flowing fluid leak fires. All other fire tests on fluid spills and flowing fluid leaks were conducted in a one quarter-scale room having dimensions of $0.75 \times 0.75 \times 0.6 \mathrm{~m}(2.5 \times 2.5 \times 2 \mathrm{ft})$ high based on reduced scale modeling techniques developed at NBS $[5,6]$ to study fire growth in rooms. Although all relevant parameters cannot be scaled, the model provides a reasonable approximation of the behavior of a full-scale room fire. The one quarter-scale room has been used successfully to characterize fires involving a variety of materials and was adopted for this program for economy and convenience in testing.

\subsubsection{Liquid Spill}

The following five cases were selected for testing:

Case (A) Fluid at a temperature $28 \operatorname{deg}$ C (50 deg F) below its flash point with a large $(6 \mathrm{~kW})$ flame in contact with the spill.

Case (B) Fluid at a temperature $56 \mathrm{deg}$ C (100 deg F) below its flash point with various sized ( 1.5 to $6 \mathrm{~kW})$ flames in contact with the spill.

Case (C) Fluid at a temperature $56 \mathrm{deg}$ C (100 deg F) below its flash point with a large $(6 \mathrm{~kW})$ isolated incidental fire in the room and a small pilot flame in contact with the spill.

Case (D) Fluld at ambient temperature with a large (6 kW) flame in contact with the spill.

Case (E) Fluid at ambient temperature with a large (12 kW) isolated incidental fire in the room and a small pilot flame above the spill.

The test conditions are summarized in table 2.

The fire tests were performed in a one quarter-scale room constructed from one-inch thick ceramic fiberboard. This box has the dimensions of $76 \times 76 \times 61 \mathrm{~cm}(30 \times 30 \times 24 \mathrm{in})$ high and an opened doorway and is shown on figure 2. About $1450 \mathrm{ml}$ of each fluid tested was poured to a depth of $0.52 \mathrm{~cm}(0.20 \mathrm{in})$ in a $38 \times 74 \mathrm{~cm}(15 \times 29 \mathrm{in})$ pan situated on the floor along one side wall of the room. This situation corresponded to 231 (6 gal) of the liquid covering half of the floor area at a depth 
of $0.52 \mathrm{~cm}(0.20 \mathrm{in})$ in a $3 \times 3 \mathrm{~m}(10 \times 10 \mathrm{ft})$ room. The basis for the scaling of the liquid spill was assumed to be the same as that used for the modeling of the room fire tests of interior finish materials [5]. Briefly stated, the modeling rules required that the quantity of material must vary in direct proportion to the floor area and the thickness of the material must not change.

Two electric "kitchen range" spiral heaters, positioned under the pan, were used to heat the liquid to the desired temperature. A gas spiral burner, $7.6 \mathrm{~cm}$ (3 in) wide, made from $0.32 \mathrm{~cm}$ (1/8-in) copper tubing having holes drilled along its top side, served as the igniter contact flame. The burner operated at heat release rates from 1.5 to $6 \mathrm{kw}(1.5$ to $6 \mathrm{Btu} / \mathrm{s})$ and was positioned in a depression at the middle of the pan, shown on figure 3 , and laid just submerged below the surface of the fluid. For the $0.3 \mathrm{kw}(0.3 \mathrm{Btu} / \mathrm{s})$ contact flame a $0.32 \mathrm{~cm}(1 / 8-\mathrm{in})$ diameter submerged tube gas burner was employed. Thermocouples were located in the fluid $3.2 \mathrm{~cm}(1-1 / 4 \mathrm{in})$ in back of and $3.2 \mathrm{~cm}(1-1 / 4 \mathrm{in})$ in front of the igniter flame. A $7.6 \times 7.6 \mathrm{~cm}$ ( $3 \times 3 \mathrm{in}$ ) reinforcement gas burner, simulating an isolated fire in the room, was located in the back corner away from the pan. Times for the occurrence of flashing in the pan, flameover and flashover were recorded for each test. The tests were terminated in Cases $A$ and $B$ if flashover had not occurred in 10 minutes. In Cases $\mathrm{C}, \mathrm{D}$ and $\mathrm{E}$, the tests were allowed to run for 15 minutes. The heat release rates of $12,6,3$ and $1.5 \mathrm{kw}(12,6,3$, $1.5 \mathrm{Btu} / \mathrm{s})$, corresponding to methane gas flow rates of $320,160,80$ and $40 \mathrm{ml} / \mathrm{sec}(40,20,10$ and $5 \mathrm{CFH})$, respectively, used for the gas burners in these tests were assumed to roughly correspond to the burning rates of a large upholstered chair, a small upholstered chair, a large wastebasket, and a small wastebasket, respectively, in a $3 \times 3 \times 2.4 \mathrm{~m}$ $(10 \times 10 \times 8 \mathrm{ft})$ high room.

\subsubsection{Flowing Liquid Leak}

Ethylene glycol, extracted naphthenicoil, polyalkylene glycol and a control fluid (light hydrocarbon oil) having closed cup flash points of $118,138,249$ and $52^{\circ} \mathrm{C}\left(245,280,480\right.$ and $\left.125^{\circ} \mathrm{F}\right)$, respectively, were selected along with several ethylene glycol-water mixtures for this phase of the work. Each fluid was preheated to a temperature above the flash point in a tank and was released through an open pipe into a pan lined with vinyl asbestos tile on the floor of a one quarter-scale model room with an open doorway. With the ethylene glycol-water mixtures the fluids were preheated above the flash point of ethylene glycol. A small pilot flame was employed near the spill. The temperatures in the tank, at the discharge end of the pipe, and in the spill were monitored. The discharge temperature was varied for each fluid in order to establish the critical temperature, required at the discharge and spill locations, for flashing to occur.

In addition to the tests in the one quarter-scale room, one fire test of the light hydrocarbon oil and two tests of an ethylene glycol-water mixture having an initial $90 \%$ glycol fraction were conducted in a larger 
test room having dimensions of $2.1 \times 2.1 \times 1.7 \mathrm{~m}(7 \times 7 \times 5.6 \mathrm{ft})$ high. These tests in a larger room were intended to show the effect of room size on the fire development and to verify the use of the smaller scale tests as a simulation of the larger scale tests. In the one quarter-scale test, $1450 \mathrm{ml}$ of the test fluid was allowed to drain.into the pan over a one-minute period, while $11300 \mathrm{ml}$ was used in the larger room test over the same time period. The quantity of fluid used in the larger room fire was increased in proportion to the floor area $[5,6]$. If flashing occurred within this period, the test was allowed to continue for another 5 minutes following the one-minute discharge of fluid to evaluate the potential for room flashover.

\subsection{Other Fire Tests \\ 2.3.1 Spray Leak}

Spray leak tests were conducted on the flulds shown in table 3 . Two spray nozzles connected to an oil pump operating at $1170 \mathrm{kPa}$ (170 psig) were used for these tests. One nozzle was a standard oil burner type rated at $0.89 \mathrm{ml} / \mathrm{sec}(0.85 \mathrm{gph})$ with a 90 degree spray angle and was used for producing the fine mist. The other nozzle was fabricated from $0.64 \mathrm{~cm}(0.25 \mathrm{in})$ copper tubing with an end cap having three number 80 drill holes and was designed to give a coarse spray. Each nozzle sprayed downward with the spray envelope having a more concentrated spray at its center axis than at its outer edges. Three pilot flames were positioned such that the center and both edges of the spray envelope were exposed to the flames. These tests were designed to evaluate the ignitability of the fluids with either fine or coarse spray patterns. Figure 4 shows the spray test setup. Both nozzles were used with the fluids operating at ambient temperature.

\subsubsection{Liquid Soaked Insulation}

All of the heat transfer fluids shown in table 3 except the $50 \%$ ethylene glycol-50\% water mixture, two ethylene glycol-water mixtures having $90 \%$ and $95 \%$ glycol fractions and the light heating o1l were used in these tests. Sections of $48 \mathrm{~kg} / \mathrm{m}^{3}\left(3 \mathrm{lb} / \mathrm{ft}^{3}\right)$ fibrous glass batting, $38 \times 104 \times 7.6 \mathrm{~cm}(15 \times 41 \times 3 \mathrm{in})$ in size, were sprayed with 5 and $15 \mathrm{ml}$ of each fluid using a siphon type paint spray gun operating at $21 \mathrm{kPa}$ ( 3 psig) and then ignited along one end with a propane torch. The distance of flame spread along the length of each specimen was noted. Time was also recorded for flame travel to the opposite end of a specimen whenever this occurred.

\section{RESULTS AND DISCUSSION}

\subsection{Flash Point}

The flash point and fire point measurements for the solar heat transfer liquids considered in this study are shown in table 1. Measured values for a light hydrocarbon oil are included for comparison purposes. 
The liquids are listed in the order of increasing flash point temperature as measured with the Pensky-Martens closed cup test. In general, the results indicated that a listing of the liquids according to increasing values of open cup flash point or fire point did not differ appreciably from the sequence given in table 1.

\subsection{Liquid Sp111}

The results of the fire tests of fluid spills in a room, whose test conditions are outlined in section 2.2.1, are indicated in tables 4 to 9 . The data for Case $A$, Indicated in table 4, showed that all of the liquids heated to $28 \mathrm{deg} \mathrm{C}$ (50 deg F) below their flash points experienced flashing and resulted in a room flashover within 10 minutes of fire exposure. Figure 5 shows that flash points of the fluids, as measured with the Pensky-Martens closed cup test, correlated reasonably well with their observed temperatures for flashing in the Case A tests. Much of the scatter in the data probably resulted from difficulties in measuring the fluid temperature at which flashing occurred in the room fire tests. Fluid temperatures were measured at two sites, and unless flashing first occurred at these sites the temperatures recorded at the onset of flashing could be too low. When flashing occurred at one of the thermocouple sites, it occasionally could not be visually detected until several seconds later when the temperature was somewhat higher. The flickering light from the gas burner and its reflection from the liquid pool tended to obscure the observation of flashing. Part of the scatter in figure 5 may be due to thermal gradients in the liquid. With the exception of the silicone oll, the higher the flash point the longer was the time for the onset of flashing. The times for room flashover for all of the heat transfer fluids, including the silicone oil, appeared to generally increase with increasing closed cup flash point values.

In Cases B and C, with the 11quid at $56 \mathrm{deg} C$ (100 deg F) below the flash point, the data in tables 5 and 6 again showed that the flash point appeared to correlate with the liquid's potential for flashing and contribution to room flashover. The recorder temperatures for flashing in these tests are also shown in figure 5. These temperatures correlated well with the closed cup flash point measurements for the fluids. As for the liquid's contribution to room flashover in the Case $B$ tests, liquids with flash points above $207^{\circ} \mathrm{C}\left(405^{\circ} \mathrm{F}\right)$ did not lead to flashover within 10 minutes with a $6 \mathrm{kw}(6 \mathrm{Btu} / \mathrm{s})$ flame contact. At the intermediate flame setting of $3 \mathrm{kw}$ ( $3 \mathrm{Btu} / \mathrm{s}$ ), all of the tests having liquids with flash points at or above $199^{\circ} \mathrm{C}\left(390^{\circ} \mathrm{F}\right)$ did not result in room flashover within a 10-minute period. For the Case $\mathrm{C}$ tests, the data indicated that liquids having flash points at and above $163^{\circ} \mathrm{C}\left(325^{\circ} \mathrm{F}\right)$ would not lead to flashover within 10 minutes for this type of fire exposure. The data in tables 7 and 8 are for Cases $D$ and $E$ where the heat transfer 1iquids were originally at ambient temperature. For Case $D$, where an incidental fire is inside the spill area, liquids with flash points at and above $118^{\circ} \mathrm{C}\left(245^{\circ} \mathrm{F}\right)$ did not experience flashing and room flashover within 10 minutes. The data for Case $E$ showed that the liquids 
having flash points at and below $138^{\circ} \mathrm{C}\left(280^{\circ} \mathrm{F}\right)$ experience flashing and room flashover within approximately 10 minutes when exposed to a moderately large isolated fire in the room.

Ethylene glycol-water mixtures were also tested in this study. This work has indicated that when such mixtures are heated the water component evaporates faster than the glycol fraction and that only mixtures having a final glycol fraction greater than approximately $95 \%$ have flash points. Table 9 compares the performance of two mixtures with pure ethylene glycol for Cases A and B. Unless the mixture was predominantly ethylene glycol it did not flash within 10 minutes under these fire conditions. Flashover was achieved for an initial mixture of $75 \%$ ethylene glycol with the mixture originally at $28 \mathrm{deg}$ C (50 deg F) below the flash point for pure ethylene glycol. For $100 \%$ ethylene glycol, flashover was achieved with the fluid originally at 56 deg C (100 deg F) below the flash point.

\subsection{Flowing Liquid Leak}

Test data on the flowing leak fires for the light hydrocarbon oil, naphthenic oil and polyalkylene glycol are presented on tables 10 to 12 . These results indicated that unless fluids have fairly high flash point values, the fluids will flash and lead to room flashover when the fluid flowing between the pipe discharge and spill locations is in the vicinity of the flash point temperature of the fluid. Tests with the polyalkylene glycol, having a flash point of $249^{\circ} \mathrm{C}\left(480^{\circ} \mathrm{F}\right)$, showed that flashing can occur with fluids having high flash points but that it may not be sustained and may not lead to flashover even when the discharge and pan temperatures exceed the flash point temperature. The data in table 10 also show the time to flashing varies widely for small changes in the discharge temperature. This indicates the discharge temperatures selected were in the region of a critical point in terms of time to flashing. This effect may be due in part to slight changes in ambient conditions between tests.

Table 13 summarizes the results of the fire tests of flowing leaks of ethylene glycol and ethylene glycol-water mixtures. In the tests with the ethylene glycol, the liquid was heated to three different tank temperatures above its flash point before it was discharged. The time for flashing was found to decrease for increasing tank temperature with the discharge temperature close to the flash point at the time of flashing in all three cases. For the fire tests with the glycol-water, the mixture was allowed to boil and increase further in temperature in order to increase the probability for flashing when it flowed over the test pan. However, in boiling the mixture, the water component evaporated more quickly than did the glycol fraction and the composition of the liquid became more concentrated with glycol. The data in table 13 showed that the boiling temperatures increased slowly with time. It took roughly 10 to 15 minutes to increase the temperature by 10 to $20 \mathrm{deg} C$ (18 to $36 \mathrm{deg}$ F), resulting in an increase of the glycol component of 5 to $10 \%$ by volume. The composition of two of the glycol-water mixtures at the 
time of flashing was determined by analyzing samples of the liquid taken at the point of discharge and at the pan surface. The samples were quickly cooled in a cold water bath and then were cooled further in an ethano1-dry ice bath to determine their freezing points. The latter are functions of the composition of the mixtures and thus can be used to indicate the glycol fraction of the liquids. Only those mixtures having an initial glycol fraction of at least $90 \%$ resulted in flashing under the conditions tested. Analysis of the mixtures at the time of flashing indicated glycol fractions of at least $95 \%$ and fluid temperatures of over $139^{\circ} \mathrm{C}\left(282^{\circ} \mathrm{F}\right)$. With ethylene glycol and the glycol-water mixtures, flashing of the liquid in every case led to fire involvement of the entire pan of liquid within 30 seconds and to flashover of the room within 100 seconds.

Results of the fire tests of the flowing liquid in the larger size room, shown in tables 10 and 13, showed no significant differences in the temperatures at the time of flashing due to room size. The number of experiments was not sufficient to correlate room size with time to flashover. With the light hydrocarbon oil the discharge temperature in the larger fire test was $13 \mathrm{deg}$ C (23 deg F) higher than the liquid used with the smaller room test and, as expected, flashing of the oil and room flashover occurred sooner. In the tests with the initial $90 \%$ ethylene glycol-10\% water mixture, the 1iquid took 14 to 18 seconds to flash in the two small room tests and 3 seconds in the larger room fire test. However, in a repeat of the same larger room test with similar discharge temperatures but with a 8 deg C (14 deg F) lower tank temperature, the liquid did not flash during the discharge period of one minute.

\subsection{Spray Leak}

All of the heat transfer liquids used for the spray fire tests, shown in table 3, ignited immediately upon contact with the pilot flames with the exceptions of the $50 \%$ ethylene glycol-50\% water mixture and the paraffinic oil having a flash point of $207^{\circ} \mathrm{C}\left(405^{\circ} \mathrm{F}\right)$. This oil was very viscous and tended to squirt and discharge in a stream with the fine and heavy spray nozzles, respectively. The ethylene glycol-water mixture tended to ignite only in the vicinity of the pilot flames and the ignition was not sustained.

\subsection{Liquid Soaked Insulation}

The results of the liquid soaked insulation tests are given in table 14. In the sprayed specimens tested after a wait of three days, the time for flame to spread along the entire length of the specimen increased with increasing flash point of the liquid with the times varying from 13 to 45 seconds for the liquids having flash points from $135^{\circ} \mathrm{C}\left(275^{\circ} \mathrm{F}\right)$ to $285^{\circ} \mathrm{C}\left(545^{\circ} \mathrm{F}\right)$. The two exceptions were the light oil and the ethylene glycol. These liquids evaporated from the insulation over the waiting period, and consequently the test specimens would not support flame spread. Insulations coated with these two liquids along 
with specimens sprayed with two glycol-water mixtures were also tested at about 5 minutes after being sprayed. Flame spread to the end of the insulation coated with the light oil took only 9 seconds while the insulations sprayed with the ethylene glycol and glycol-water mixtures took about 3 minutes for the same flame spread distance. The data also showed that insulation coated with three times as much liquid experienced a slower flame spread.

\section{SUMMARY OF EXPERIMENTAL FINDINGS}

Room fire tests of solar liquids indicate that:

1. Liquids will flash in the presence of a nearby pilot flame, similar to that in a water heater, when their temperatures are in the vicinity of the closed cup flash point values for the liquids.

2. The 1iquids tested, with the exception of some ethylene glycolwater mixtures, will ignite and lead to room flashover when the fluid covers one half of the floor area and is exposed to a moderate contact flame, equivalent to an upholstered chair.

3. The liquids tested, with the exception of some ethylene glycol-water mixtures and the paraffinic oil having a flash point of $207^{\circ} \mathrm{C}\left(405^{\circ} \mathrm{F}\right)$, will ignite immediately when sprayed into a pilot flame.

4. Ethylene glycol-water mixtures must have a glycol fraction of approximately $95 \%$ by volume before flashing can occur in the presence of a pilot flame.

5. The rate of flame spread along fibrous glass insulation sprayed with the solar heat transfer fluids was higher for liquids having low flash point temperatures.

\section{DEVELOPMENT OF CRITERIA}

The sustained ignition of a liquid pool of the heat transfer liquid within a structure is considered an unacceptable condition since it can result in the generation of heat, smoke and toxic products of combustion leading to the spread of fire and to untenable conditions. The fire tests have demonstrated that sustained ignition of these 1iquids will occur in a room when they are at or above their closed cup flash point temperatures. These results indicate that the closed cup flash point is a suitable basis for the criteria which are consistent with NFPA No. 321. Since the ignition of the heat transfer liquid is unacceptable and ignition sources are likely to be present, the temperature of the liquid must be below the flash point if it is accidentally discharged into a building. 
A rational analysis of the potential accident scenarios can contribute significantly to the development of the criteria. For the case of a leak in the piping system resulting in a pool of liquid the system may be in operation with all of the liquid at the maximum operating temperature. Since the liquid may discharge rapidly and have little time to cool, the liquid should have a flash point significantly above its operating temperature in order to avoid ignition. A safety factor should be provided to allow for tolerances in the prediction and control of maximum operating temperature. In this case the closed cup flash point should be at least $28 \mathrm{deg} C$ (50 deg F) greater than the maximum operating temperature in order to provide a margin of safety so that a non-hostile ignition source would not ignite a liquid spill even with some localized heating. The $28 \mathrm{deg} \mathrm{C}(50 \mathrm{deg} \mathrm{F})$ safety allowance may not provide protection for liquids exposed to a moderate size or larger ignition source. The tests have indicated that any liquid with a flash point can be ignited when exposed to a sufficiently large ignition source. The criteria could have been based on the open cup flash point or fire point with the use of a different safety factor.

For comparison purposes, the flash point of home heating oil is approximately $28 \mathrm{deg} \mathrm{C} \mathrm{(50} \mathrm{deg} \mathrm{F)} \mathrm{greater} \mathrm{than} \mathrm{normal} \mathrm{ambient} \mathrm{temperature.}$ The proposed requirement is designed to provide a level of safety for solar heating systems which is basically equivalent to the level of safety found in most home oll heating systems.

If a substantial leak occurs in the piping network away from the collector area while the system is in the no-flow condition, one would expect the discharge of some liquid which was contained in the pipes at close to the operating temperature, followed by the liquid from the collectors. The liquid from the collectors will cool as it moves through the piping system towards the discharge point. The rate of cooling will be a function of the heat transfer characteristics of the piping system, the quantity of liquid in the collectors and the liquid transit time between the collectors and the discharge point. In addition, if a pool of liquid forms below the discharge point, the liquid from the collectors will mix with the liquid from the piping creating a mixture with a temperature between that of the two liquids. In order to reduce the probability that the temperature of the mixture is above the flash point, the no-flow temperature should only be permitted to exceed the flash point by a limited temperature difference. Although this maximum temperature difference will vary from system to system and with the location of the leak for a given system, it is desirable to have a single specified temperature difference rather than a complex calculation scheme. A panel of fire experts agreed on a temperature difference of $111 \mathrm{deg} C$ (200 deg F) for the case where the collector manifold assembly is located outside of the building and exposed to the weather.

If a leak occurs in the collector or in the piping network in the vicinity of the collector while the system is in the no-flow condition, the liquid would discharge at approximately the no-flow temperature. It is expected that most leaks will occur in the manifold piping connecting 
the collectors rather than in the collectors themselves. If the manifold piping is outside of the building, the leaking fluid would normally cool substantially even if it were to subsequently enter the structure. This inciudes situations in which the manifold is outside the building with a single pipe run leaving the manifold and entering the structure. The ignition of the liquid on the roof from external sources is considered relatively unlikely.

If the manifold piping is exposed within the interior of the building, a leak in this piping would introduce liquid at the no-flow temperature directly into the structure. The condition may be more hazardous in attic areas where higher ambient temperatures could reduce the normal rate of liquid cooling. To reduce the possibility of ignition of the liquid leaking from collector manifolds which are inside the building, the maximum no-flow temperature should not exceed the flash point of the liquid.

In the case of a spray leak in the piping system, the fire tests showed that when a spray is discharging directly into a flaming ignition source, the high area to mass ratio of the liquid particles will result in rapid heating and ignition of the liquid even when a relatively high flash point liquid is involved. If the spray occurred in the attic the insulation soaked with the liquid provides an additional potential fire problem. However, the probability of a spray leak directly into a flame or of the soaked insulation coming in contact with a flame is estimated to be rather low.

Another type of system discharge is the operation of a pressure relief valve or the opening of a drain or fill point. Systems using non-potable heat transfer liquids will frequently be required to have pressure relief valves and catchment basins connected to drains. Liquid discharging into a catchment basin or sewer system will cool rapidly. If a catchment basin is not provided, the previous scenarios should adequately cover the discharge from a drain or pressure relief valves. This discharge may be in the form of a spray, drip, or substantial leak with the system in either the operating or no-flow condition.

\section{PROPOSED CRITERIA}

Based on the results of the fire tests and of the analysis of potential accident scenarios in this investigation and in a related study [7], the following proposed interim acceptance criteria for solar heat transfer liquids are recommended:

\section{Criteria}

Liquid flash point. The flash point of a heat transfer liquid shall equal or exceed the higher temperature as determined by $A$ and B below. 
A. $28 \mathrm{deg} \mathrm{C}(50 \mathrm{deg} \mathrm{F}$ ) above the design maximum operating temperature of the fluid in the solar energy system;

B. (1) $111 \mathrm{deg} C$ (200 deg F) below the design maximum no-flow temperature of the fluid attained in the collector provided the collector manifold assembly is located outside of the building and exposed to the weather and provided that relief valves located adjacent to the collector or collector manifold do not discharge directly or indirectly into the building and such discharge is directed away from flames and ignition sources; or

(2) the design maximum no-flow temperature of the fluid in all other manifold and relief valve configurations.

The flash point of liquids used in industrial occupancies as defined by NFPA No. 101 [9], may be lower subject to the approval of the authority having jurisdiction.

A "heat transfer 1iquid" is defined as the operating or thermal storage liquid including water or other liquid base and all additives at the concentration used under operating conditions. The flash point shall be determined by the closed cup methods described in NFPA No. 321, Basic Classification of Flammable and Combustible Liquicis [2]. Liquids classified as flammable (flash point below $100^{\circ} \mathrm{F}$ ) shall not be used. In systems using a gaseous heat transfer fluid, a flammable gas shall not be used.

The design maximum operating temperature of the fluid is defined as the maximum fluid temperature that will be obtained when the heat transfer fluid is flowing through the system. The design maximum no-flow temperature of the fluid is defined as the maximum fluid temperature that will be obtained when the heat transfer fluid is not flowing through the system.

\section{Evaluation}

An acceptable way of determining the design maximum operating temperature is by the limiting action of control devices or relief valves, or through theoretical or test analysis of the system. An acceptable method of determining the maximum no-flow temperature is presented in test method 7.2 (section 7.2.5.2) of NBSIR 78-1305A [8] where the design maximum no-flow temperature of the fluid is equal to the plate temperature at stagnation. It should be noted that this method is not valid for collectors with very low loss coefficients.

\section{Commentary}

Flash point values listed in manufacturers' literature are commonly average or typical values and some may be based on open cup flash point tests. Flash point values used should be based on actual measurement or 
certifled minimum values determined on representative samples by the Pensky-Martens closed cup flash point test method ASTM D 93 for liquids with a flash point at or above $93.4^{\circ} \mathrm{C}\left(200^{\circ} \mathrm{F}\right)$ or the Tag closed cup flash point test method ASTM D 56 for 11quids with a flash point below $93.4^{\circ} \mathrm{C}\left(200^{\circ} \mathrm{F}\right)$.

The flash point of aqueous solutions of organic liquids depends on the percentage of water in the mixture. In the case of ethylene glycol, a flash point does not exist for certain percentages of ethylene glycol with water. When these mixtures are slowly heated and the vapors allowed to escape, the flash point of the mixture usually will be reduced, ultimately approaching that of pure ethylene glycol. Care should be taken that the flash point of the solution test sample is based on the anticipated percentage of water during actual use of the liquid in the system and not necessarily on the percentage as installed.

\section{ACKNOWLEDGMENTS}

Appreciation is expressed to Mr. C. Veirtz who performed the tests and to Mr. W. J. Parker who helped considerably in developing the flash point criteria and whose suggestions resulted in more meaningful fire tests of the solar heat transfer liquids.

This project was sponsored by the Department of Energy under the direction of Mr. Arnold Weintraub.

\section{REFERENCES}

[1] Fire Protection Handbook, Fourteenth Edition, Section 3, Chapter 3, pp. 3-19 through 3-21, 1976, National Fire Protection Association, 470 Atlantic Avenue, Boston, Mass. 02210.

[2] Basic Classification of Flammable and Combustible Liquids, NFPA No. 321, 1976, National Fire Protection Association, 470 Atlantic Avenue, Boston, Mass. 02210.

[3] Standard Method of Test for Flash Point by Pensky-Martens Closed Tester, ASTM D 93-73. American Society for Testing and Materials, Philadelphia, Pa.

[4] Standard Method of Test for Flash and Fire Points by Cleveland Open Cup, ASTM D 92-66. American Society for Testing and Materials, Philadelphia, Pa.

[5] Parker, W. J. and Lee, B. T., A smal1-scale enclosure for characterizing the fire buildup potential of a room, Nat. Bur. Stand. (U.S.), NBSIR 75-710 (June 1975). 
[6] Lee, B. T. and Breese, J. N., Submarine compartment fire study fire performance evaluation of hull insulation, Nat. Bur. Stand. (U.S.), NBSIR 78-1584 (May 1979).

[7] Holton, J. K., Interim performance criteria for solar heating and cooling systems in residential buildings: second edition, Nat. Bur. Stand. (U.S.), NBSIR 78-1562 (Nov. 1978).

[8] Waksman, D., Streed, E. R., Reichard, T. W. and Cattaneo, L. E., Provisional flat plate solar collector testing procedures: first revision, Nat. Bur. Stand. (U.S.), NBSIR 78-1305A (June 1978).

[9] Life Safety Code, NFPA No. 101, 1976, National Fire Protection Association, 470 Atlantic Avenue, Boston, Mass. 02210. 


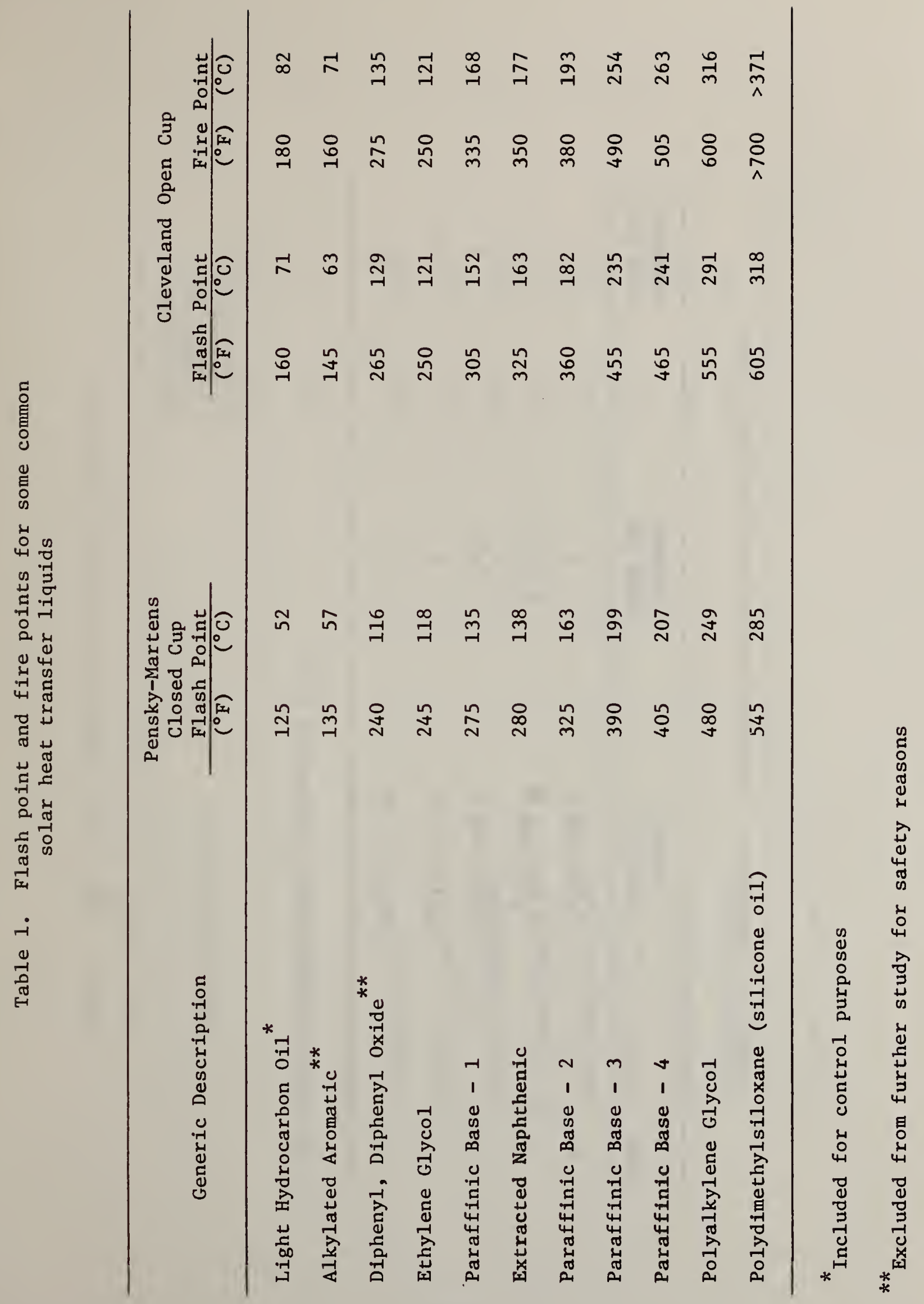




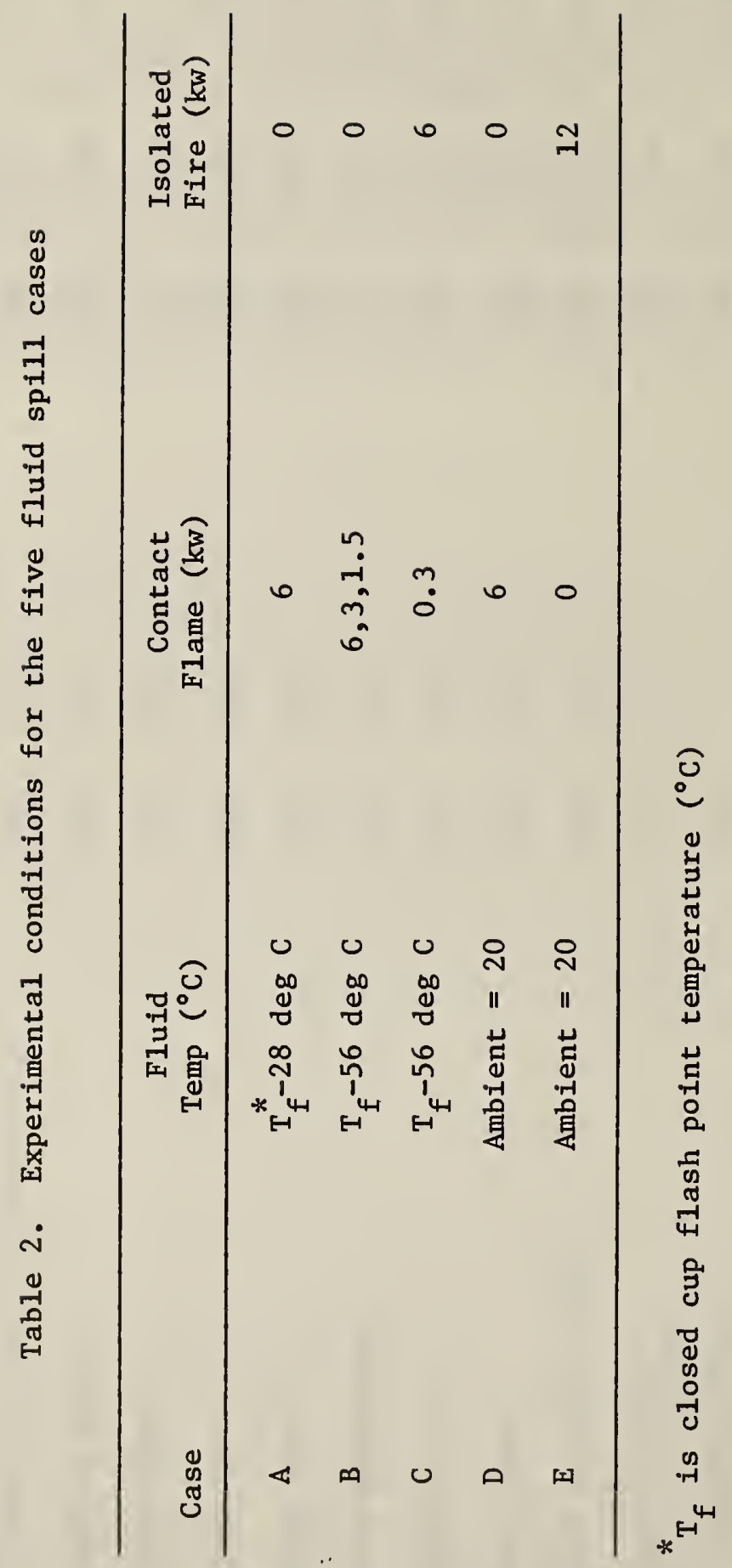




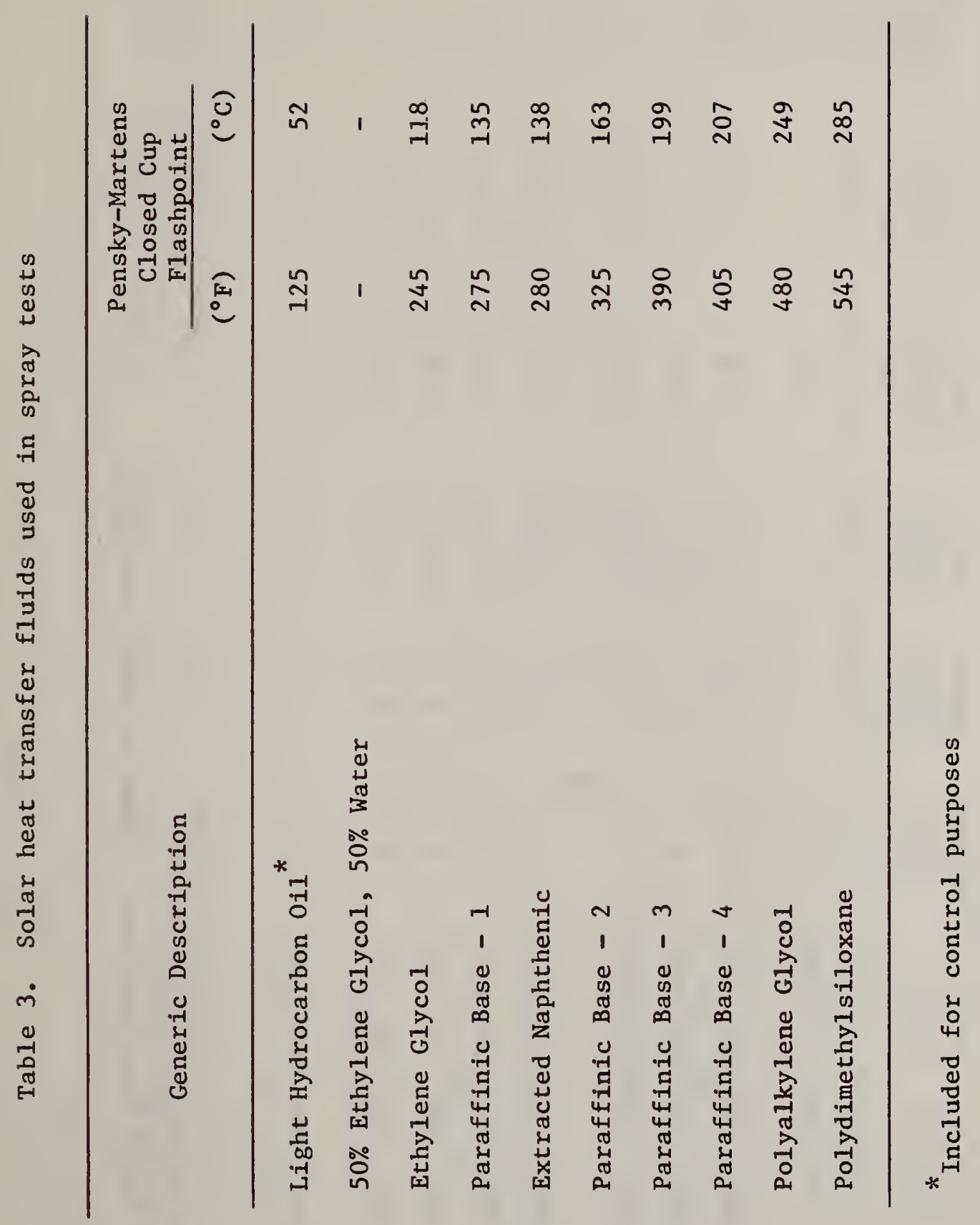




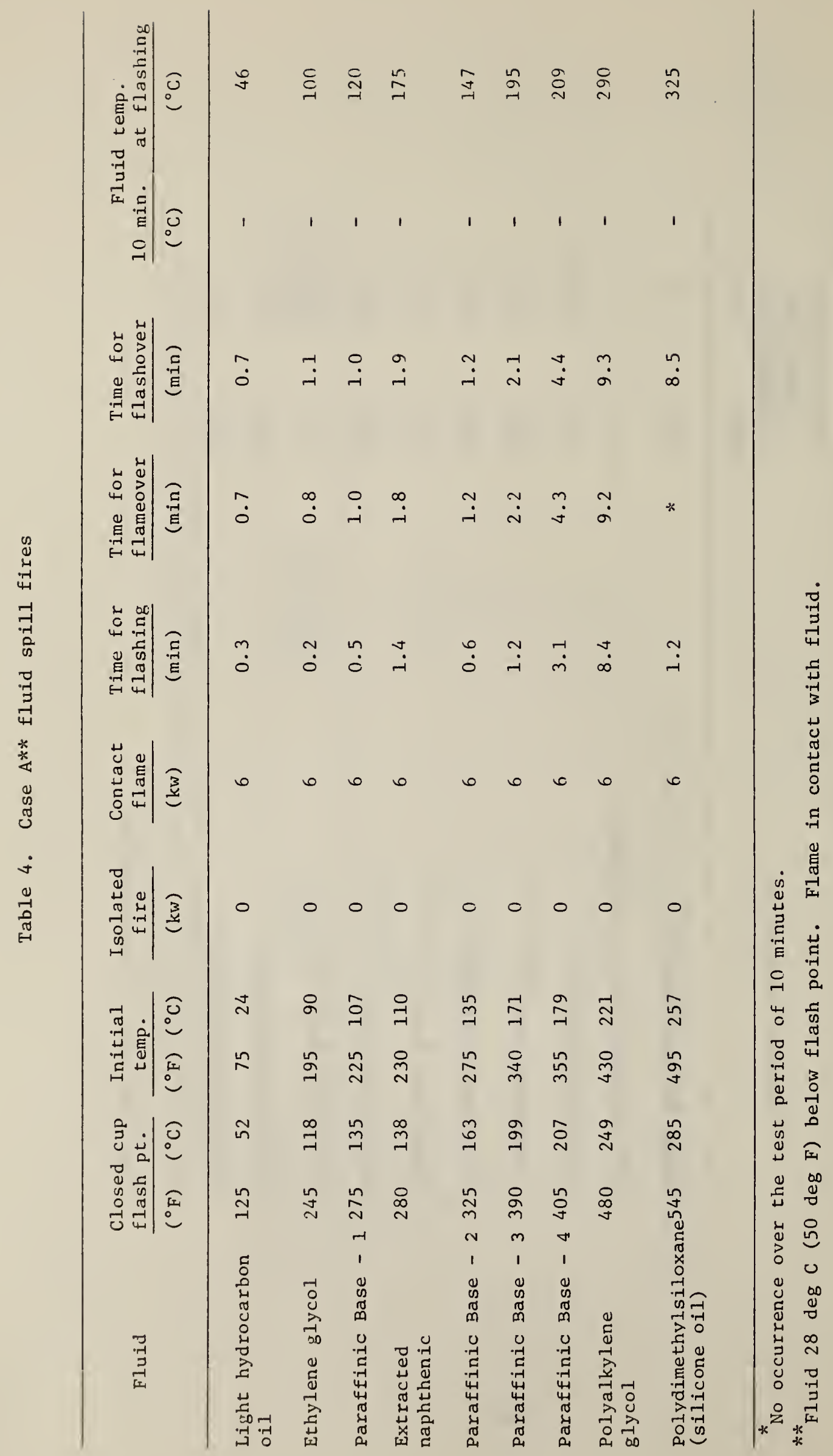




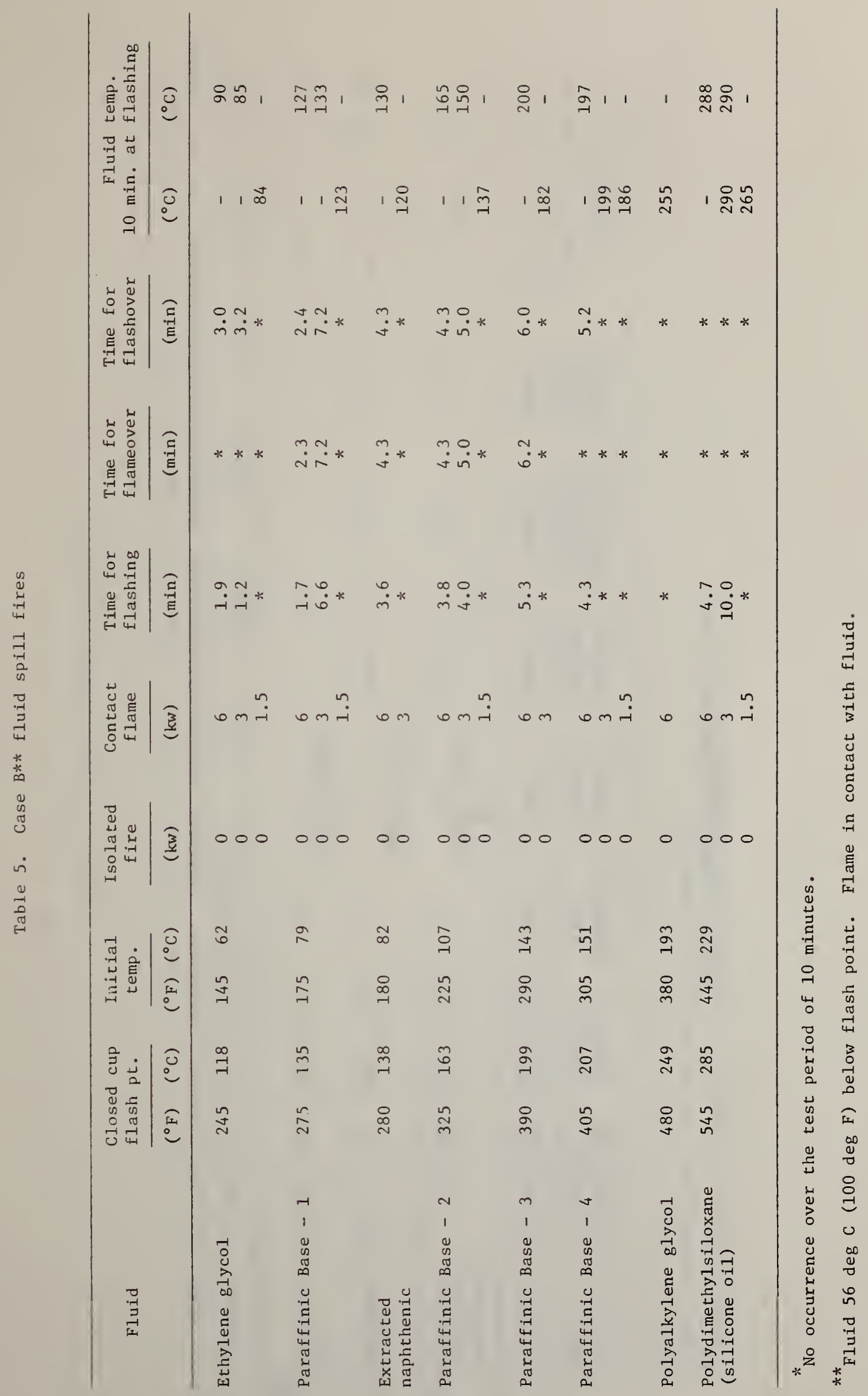




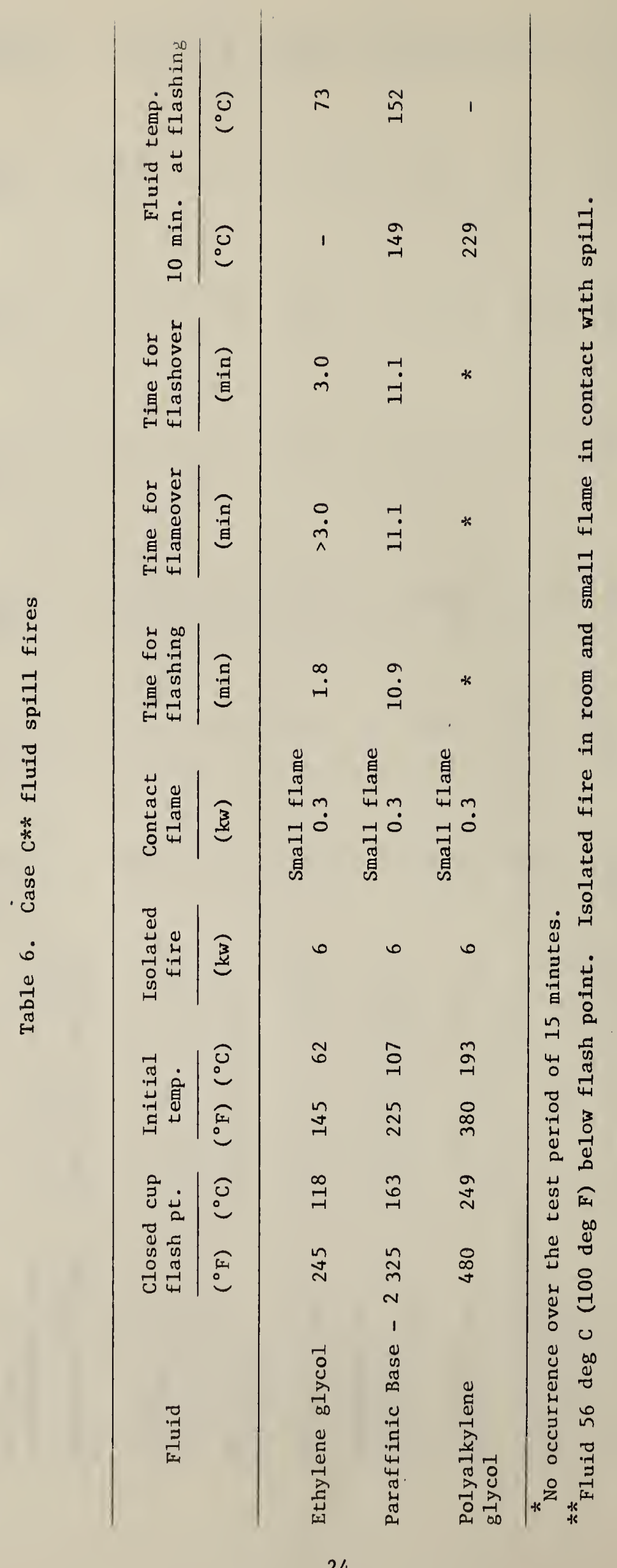




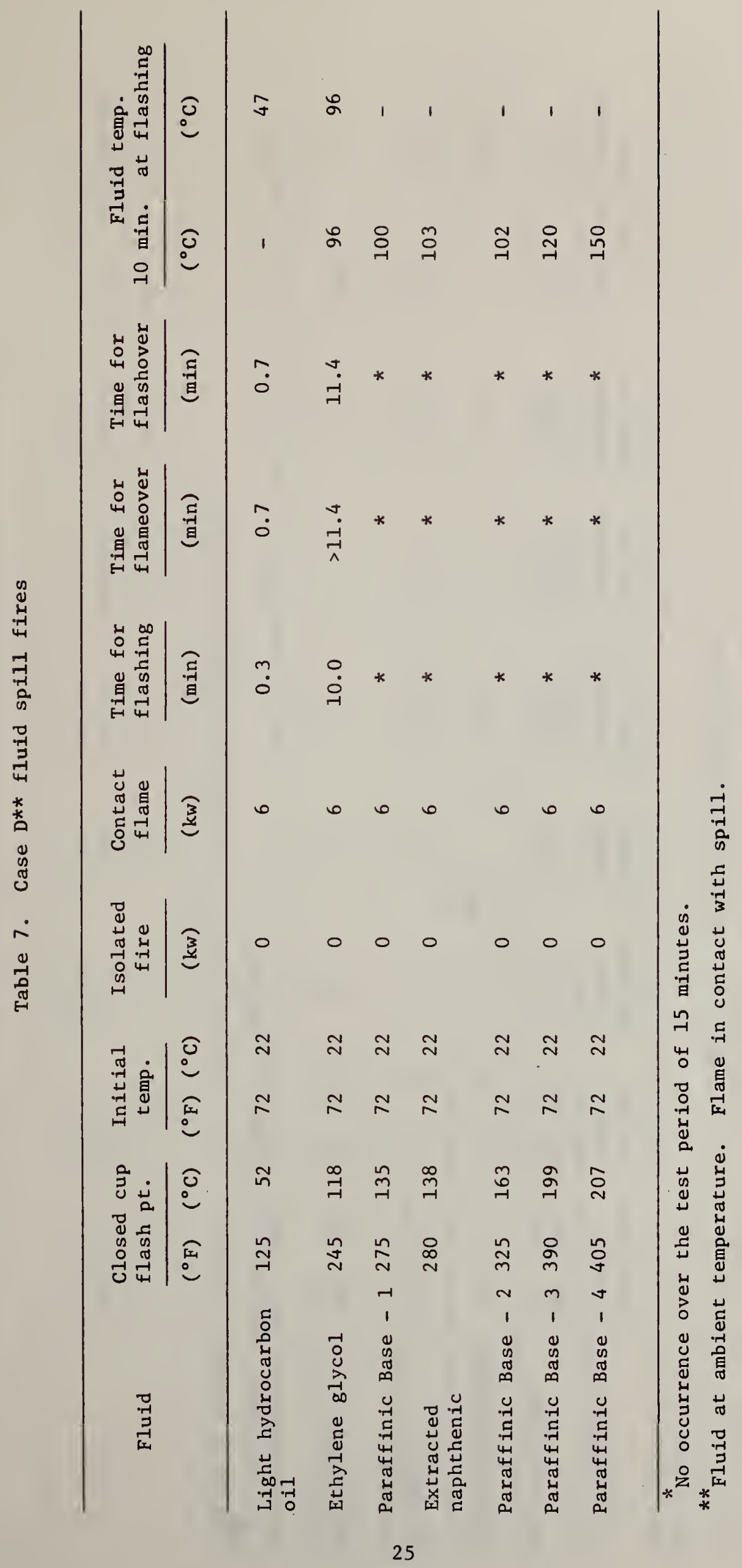




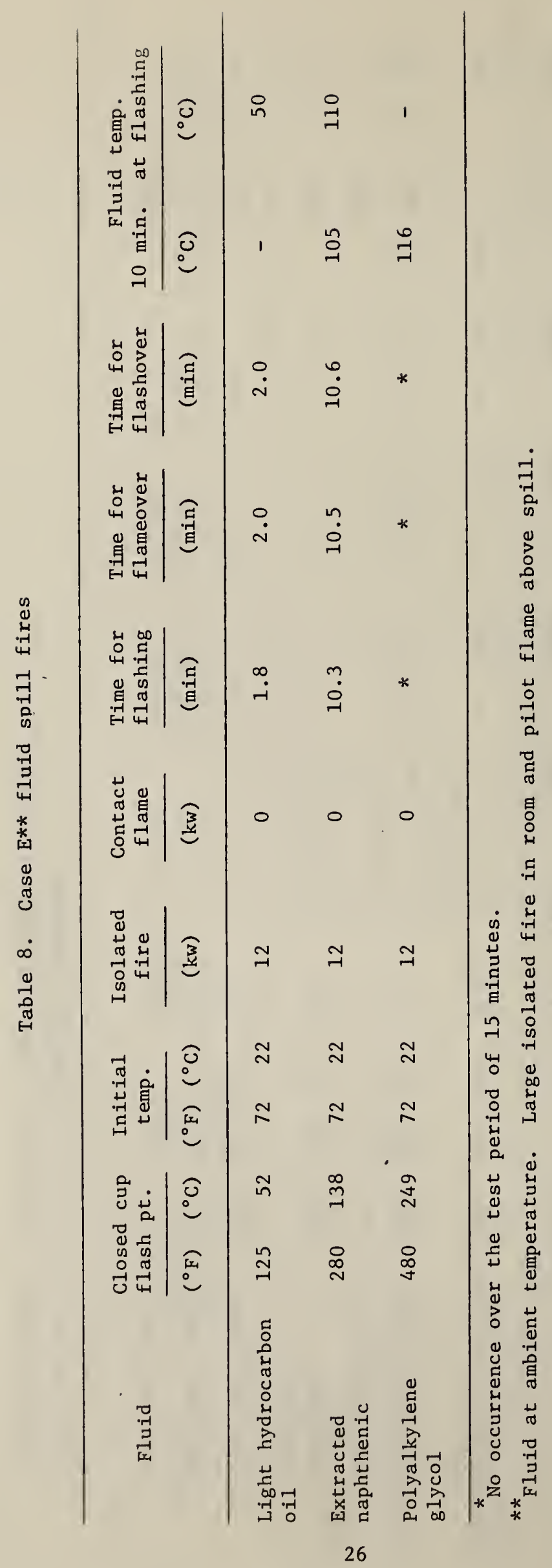




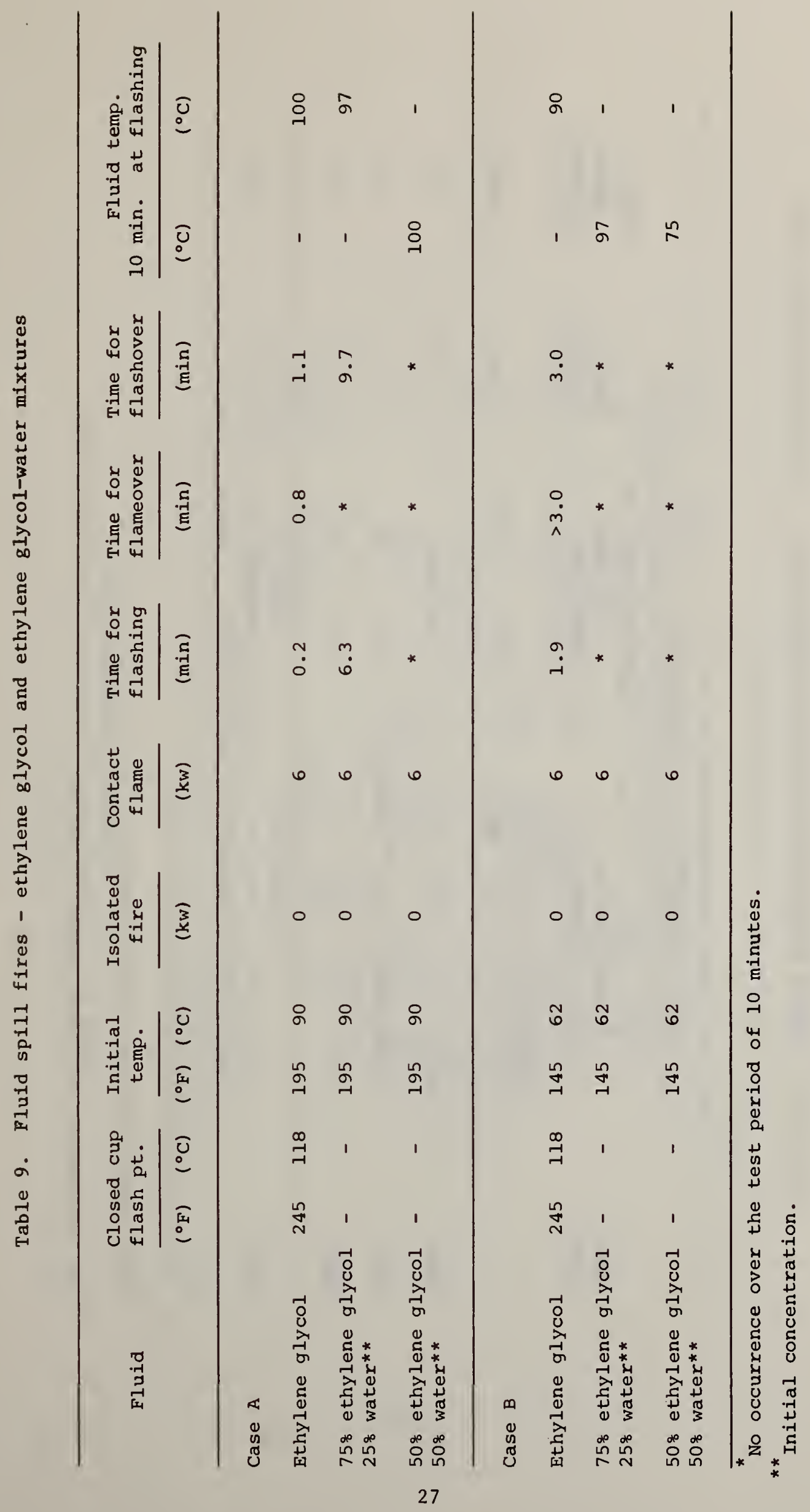




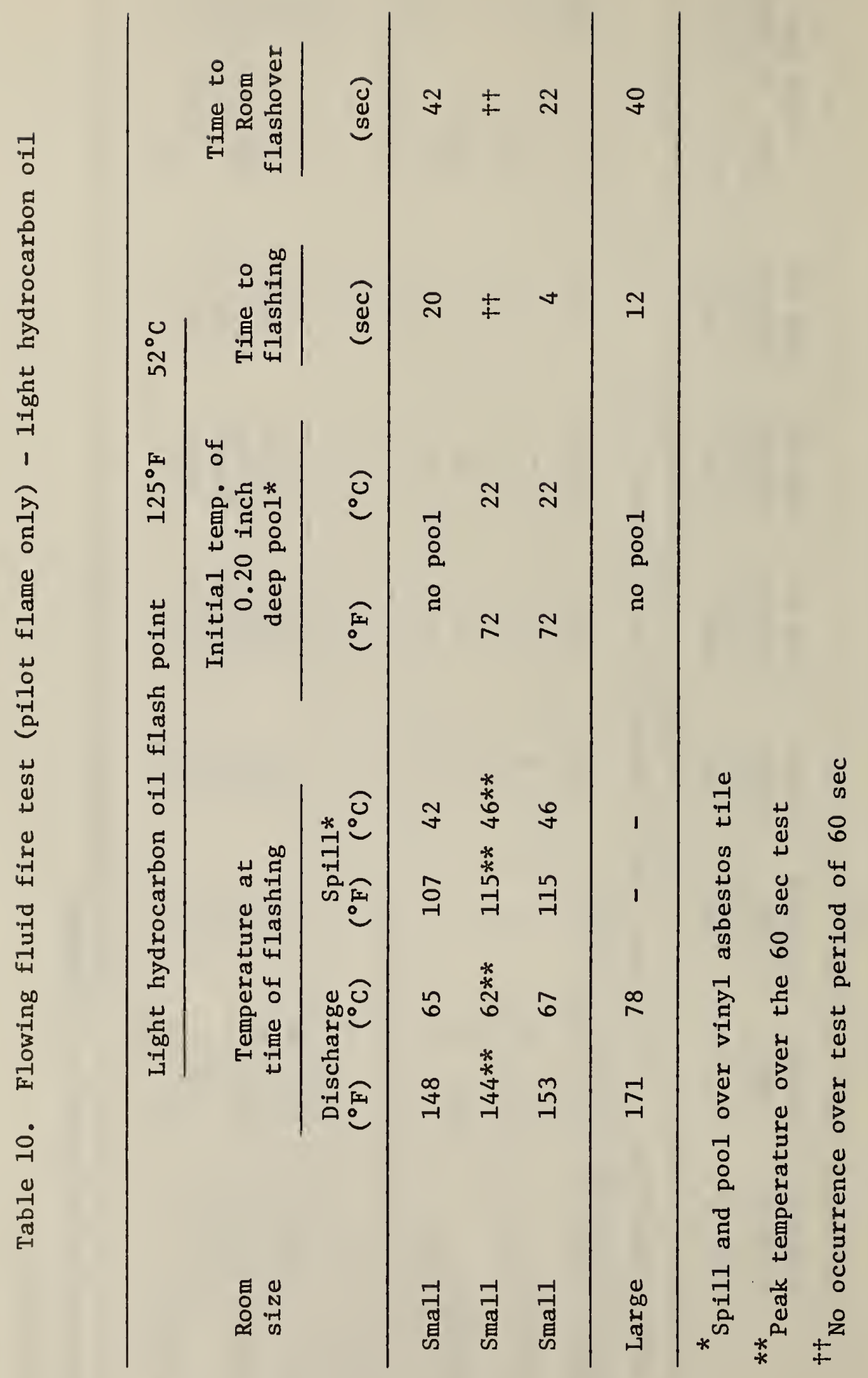




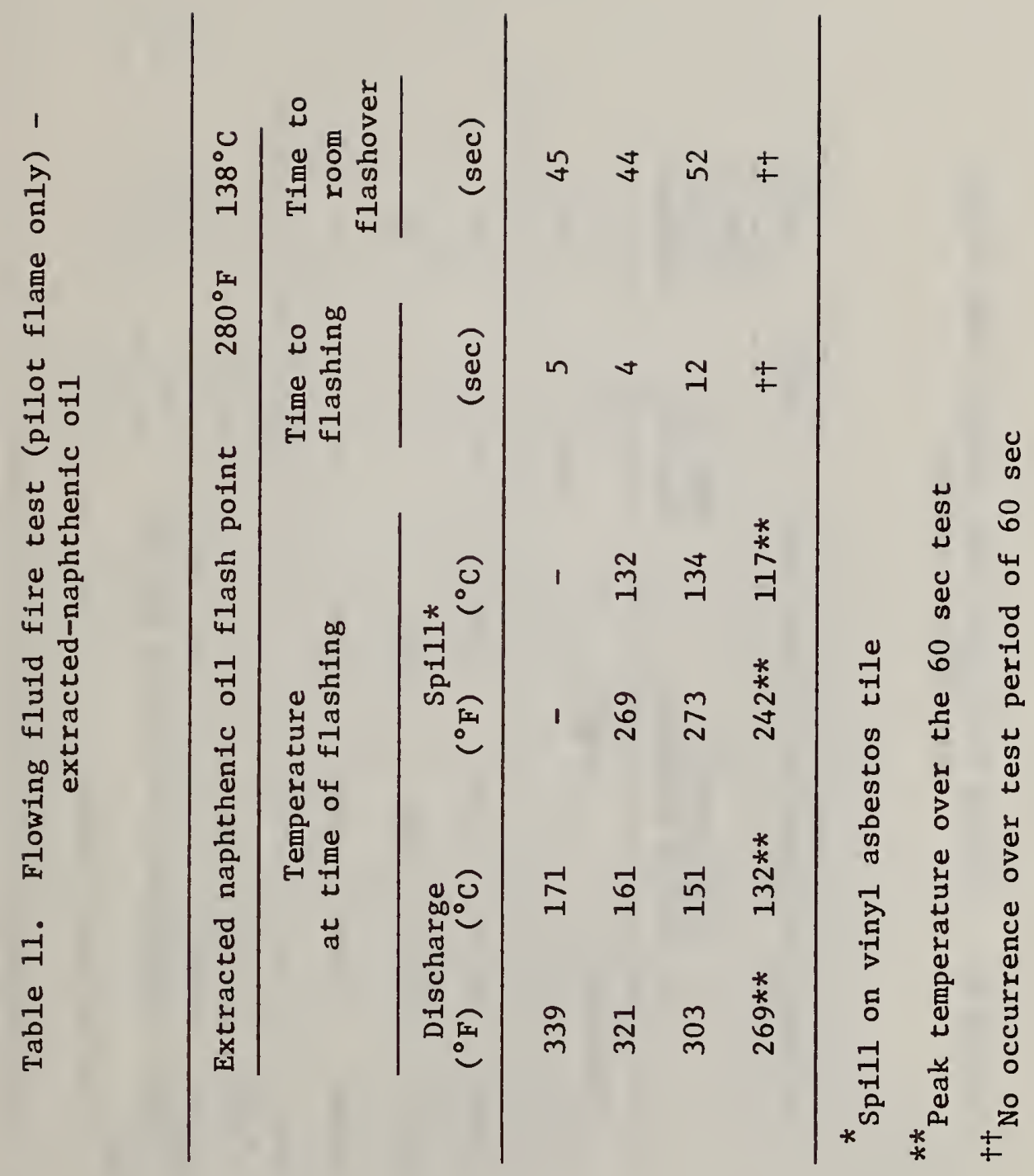




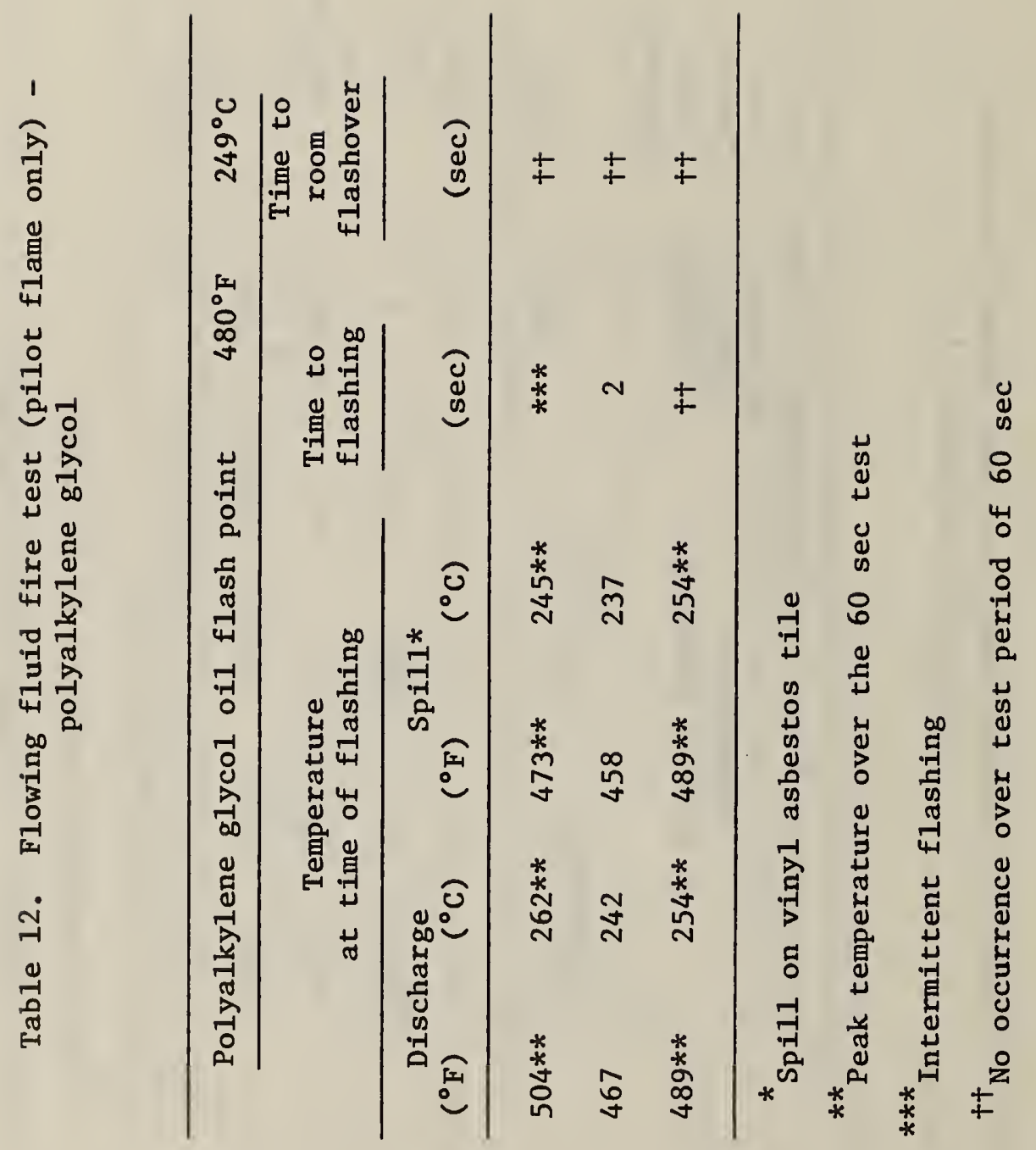




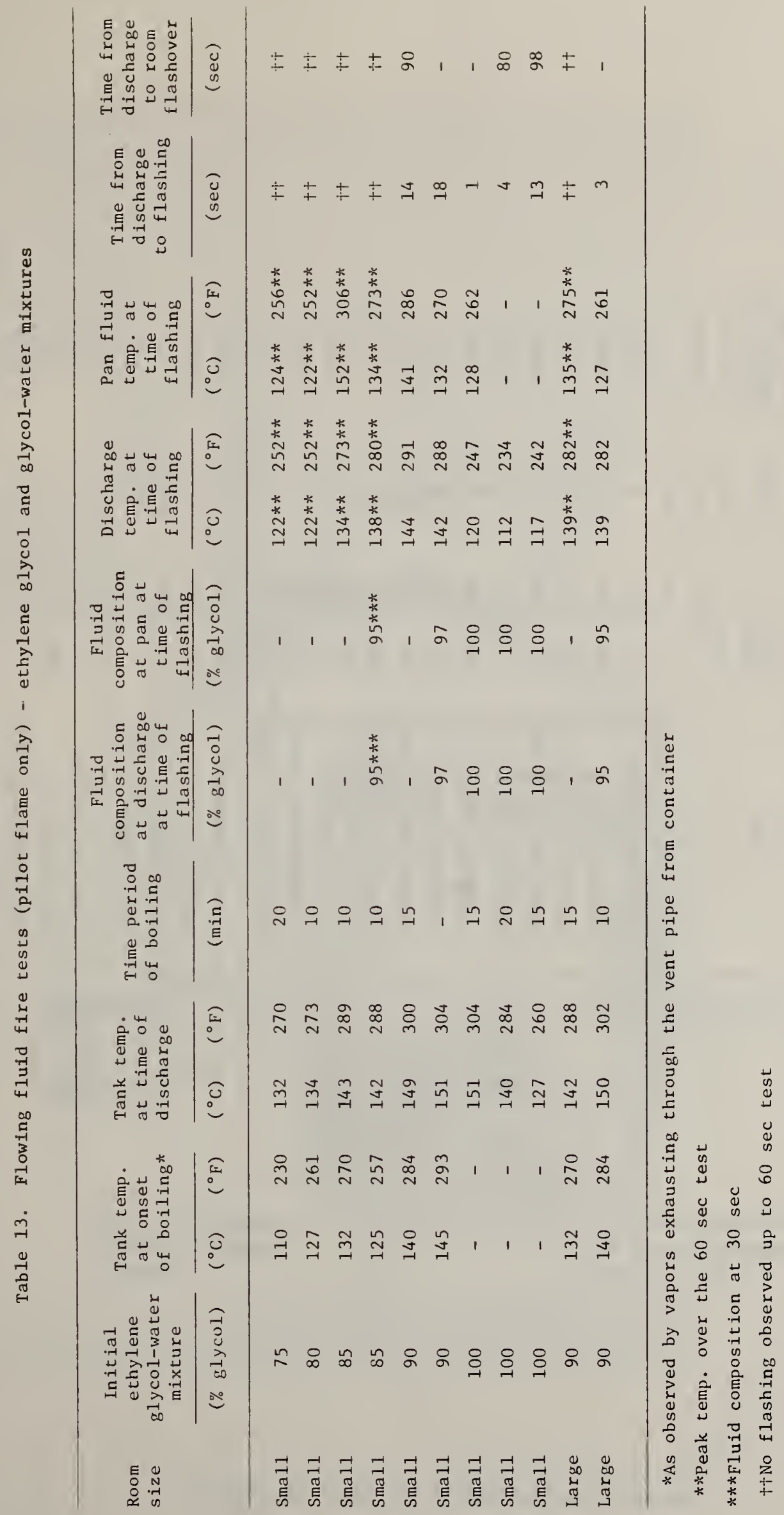




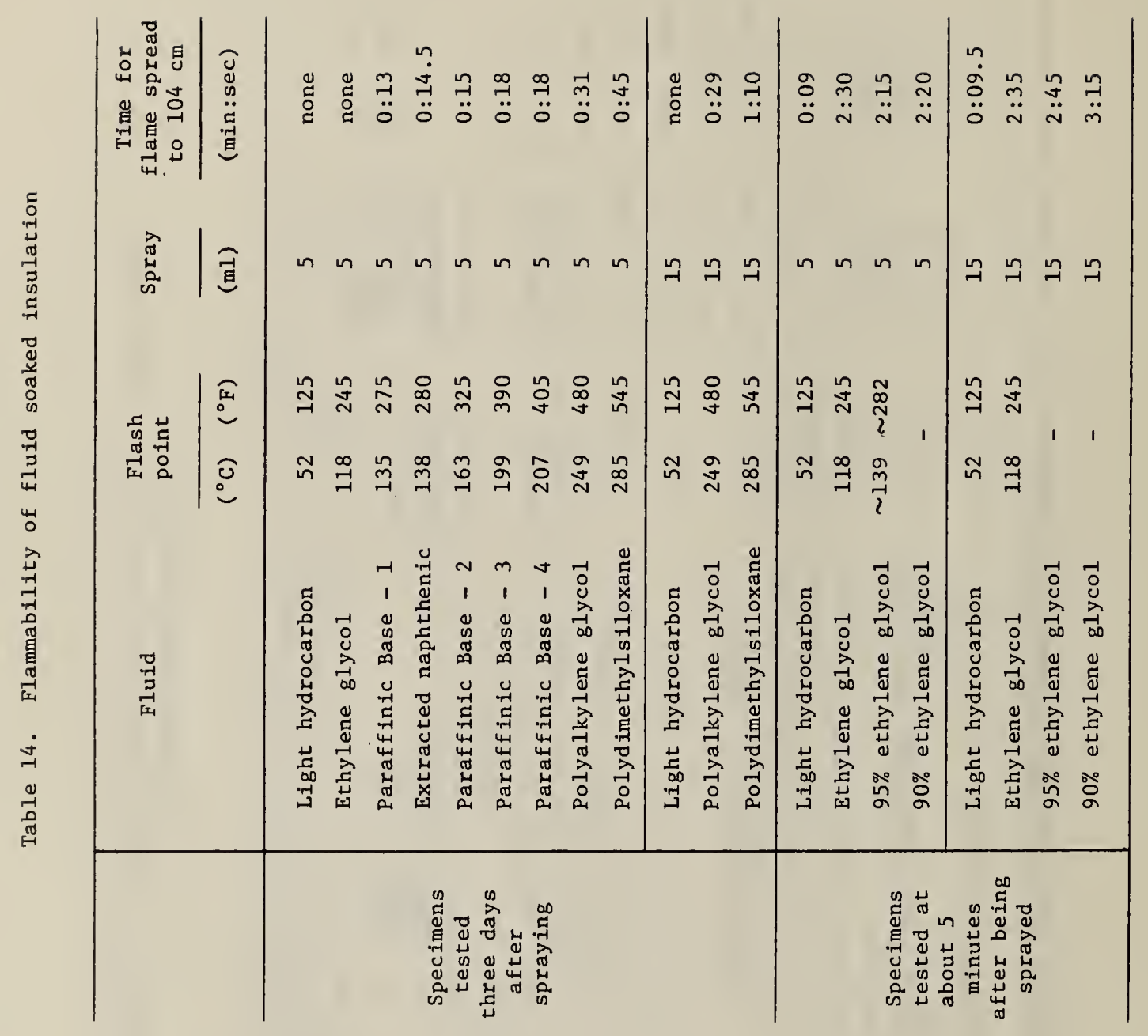




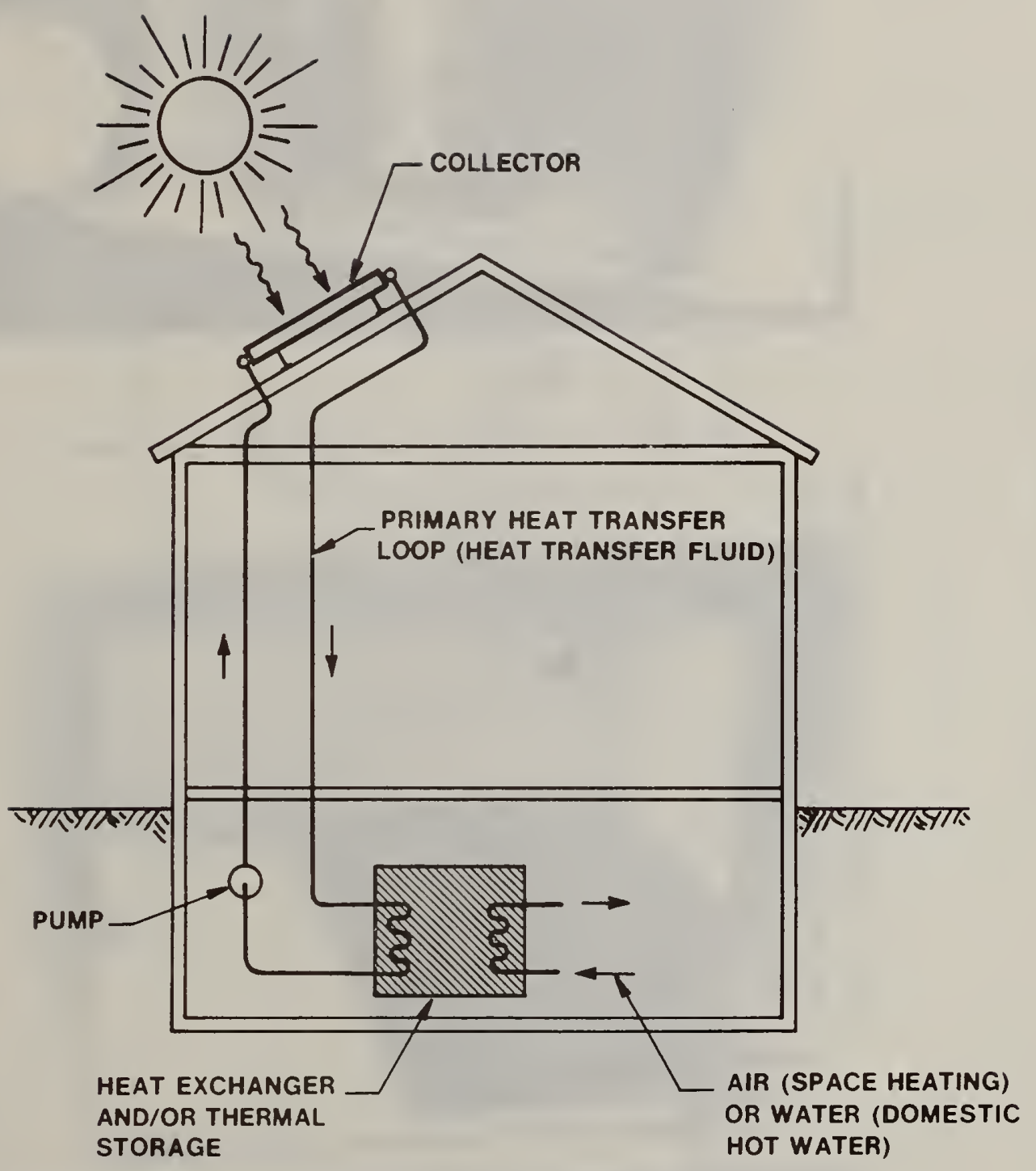

Figure 1. Active solar energy system 


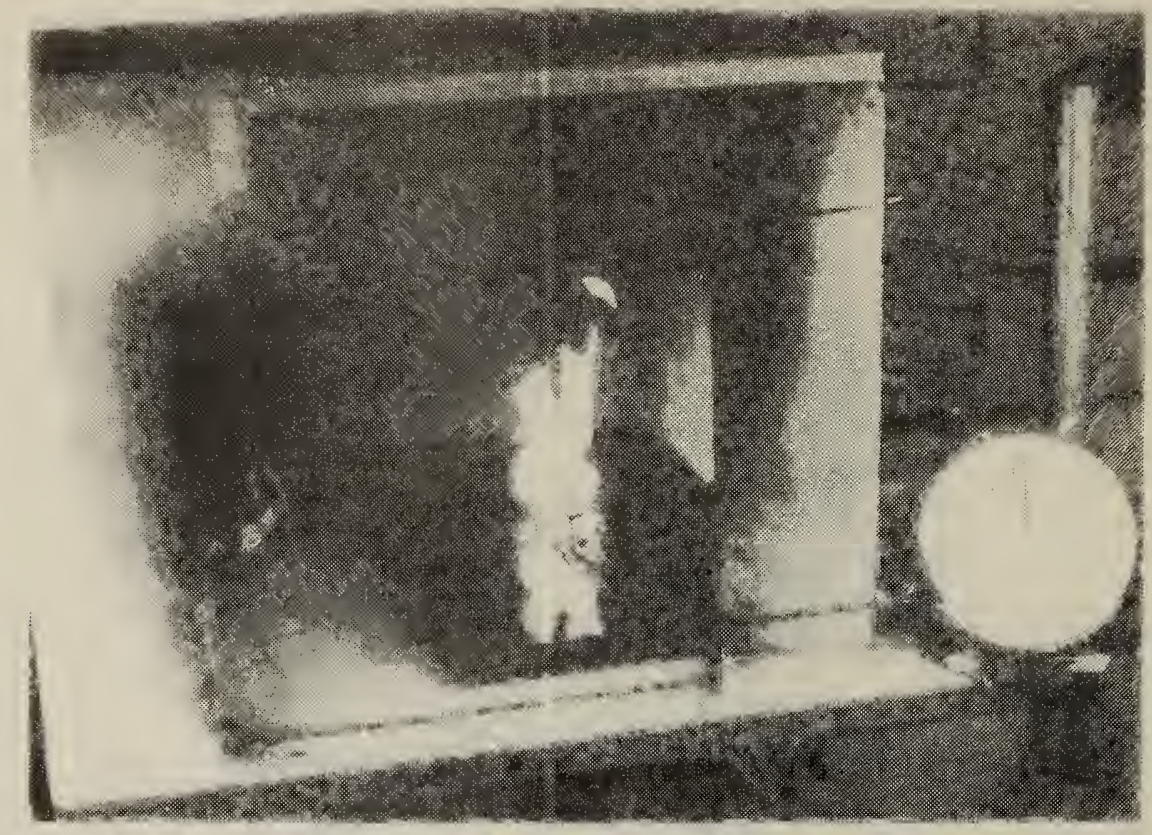

Figure 2. Reduced scale room fire test

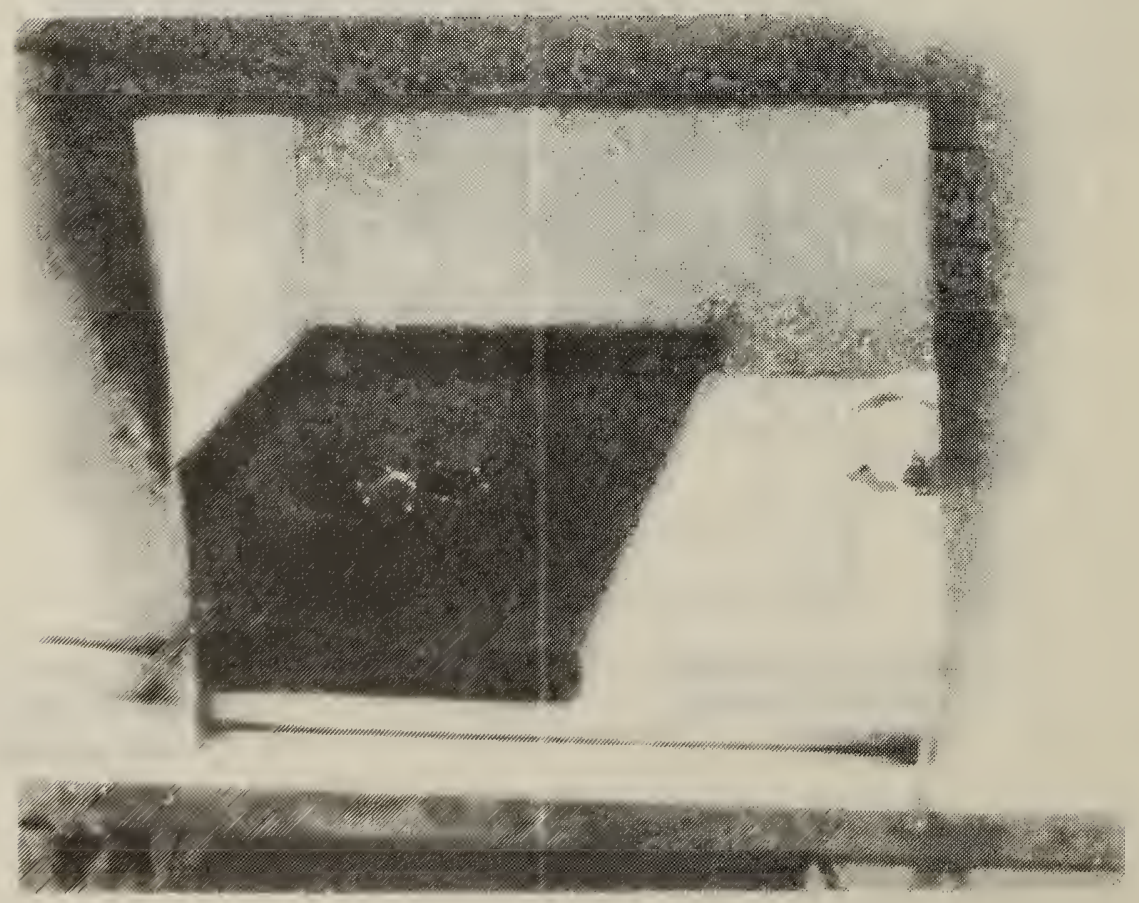

Figure 3. Fluid spill test pan with spiral gas burner in place 34 


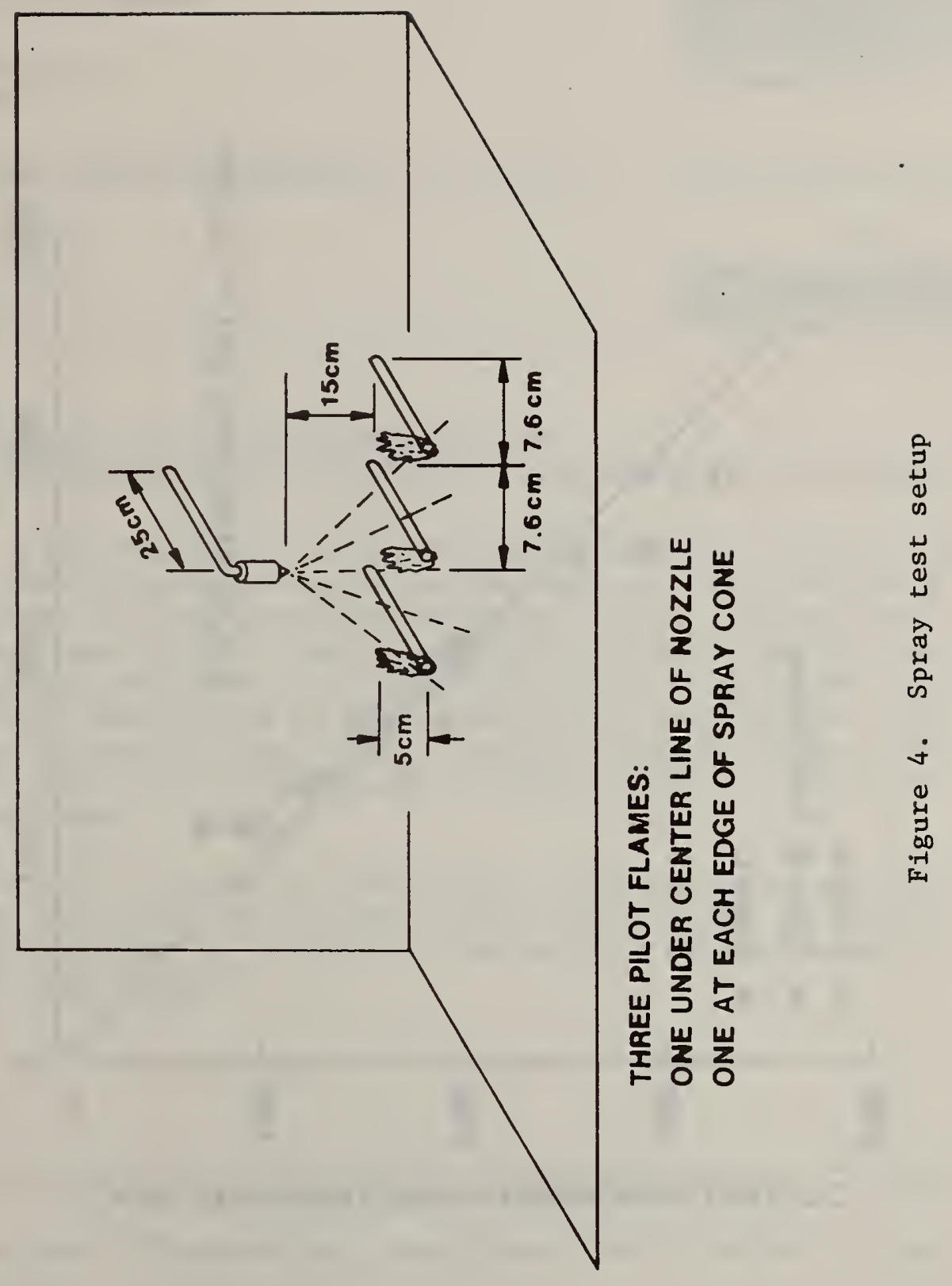




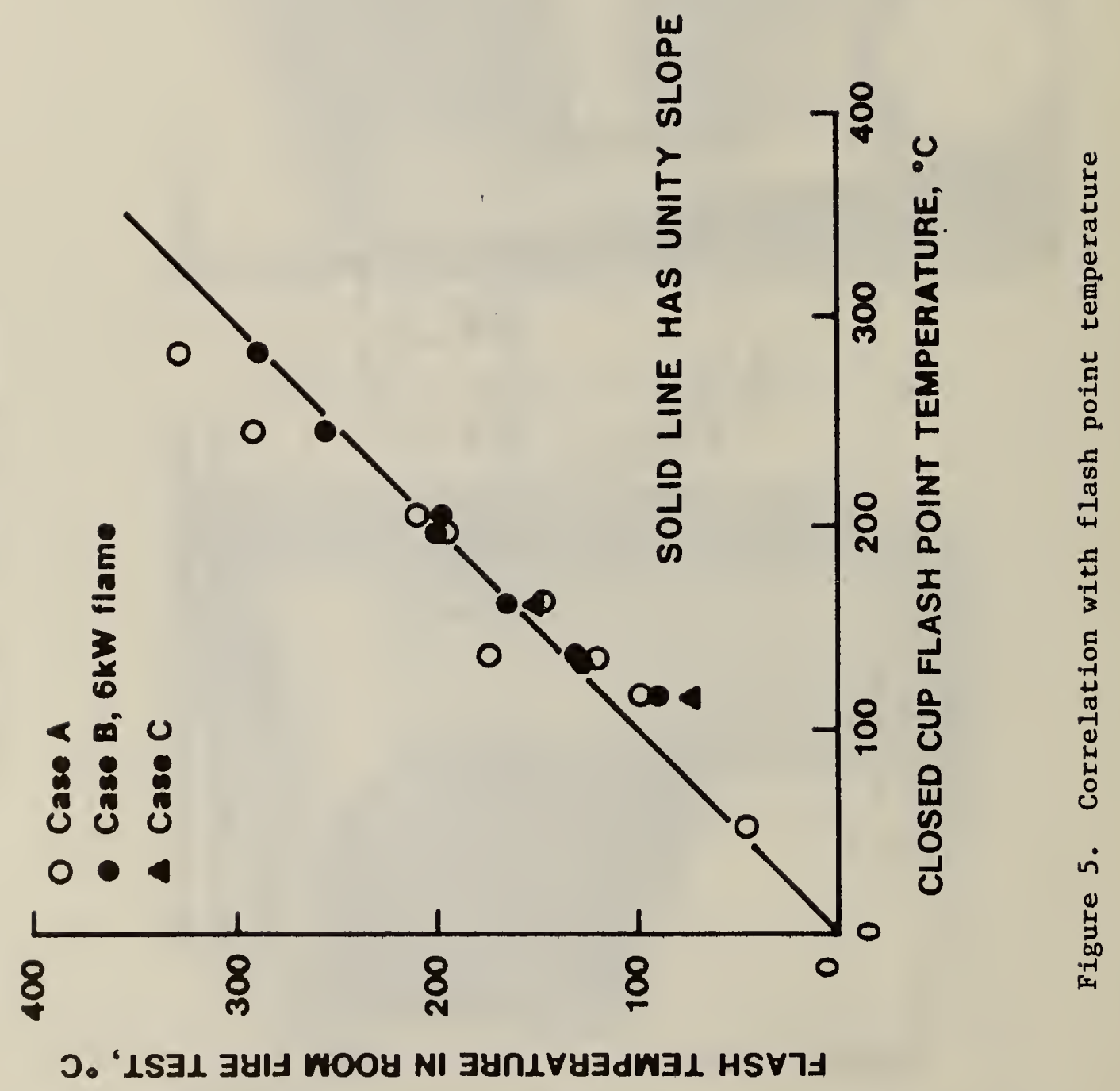


NBS. $114 A$ (REV. 9-78)

\begin{tabular}{|c|c|}
\hline $\begin{array}{l}\text { U.S. DEPT. OF COMM. } \\
\text { BIBLIOGRAPHIC DATA } \\
\text { SHEET }\end{array}$ & $\begin{array}{l}\text { 1. PUBLICATION OR REPORT NO. } \\
\text { NBSIR 79-1931 }\end{array}$ \\
\hline
\end{tabular}

4. TITLE AND SUBTITLE

Fire Experiments and Flash Point Criteria for Solar

Heat Transfer Liquids

7. AUTHOR(S)

B. T. Lee and W. D. Walton

9. PERFORMING ORGANIZATION NAME AND ADDRESS

NATIONAL BUREAU OF STANDARDS

DEPARTMENT OF COMMERCE

WASHINGTON, DC 20234

12. SPONSORING ORGANIZATION NAME AND COMPLETE ADDRESS (Street, city, state, ZIP)

Department of Energy

Washington, D.C. 20545

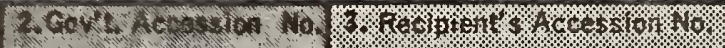

5. Publication Date

November 1979

T. Peromine Orgakization code

8. Performing Organ. Report No.

15. SUPPLEMENTARY NOTES

Document describes a computer program; SF-185, FIPS Software Summary, is attached.

16. ABSTRACT (A 200-word or less factual summary of most significant information. If document includes a significant bibliography or fiterature survey, mention it here.)

To help provide a rational basis for developing flammability criteria for heat transfer fluids used in solar energy collection systems, fire tests were performed using simulated accident scenarios involving spills, flowing leaks, spray leaks, and soaked insulation. These experiments indicated that the flash point temperatures, as measured with the Pensky-Martens closed cup apparatus, are close to the minimum temperatures at which pools of the fluids will support a flame when they are exposed to a small pilot igniting flame in a room. The heat release from moderate sized burning pools of these liquids is sufficient to cause flashover in a room.

Interim flash point criteria of at least 28 deg C (50 deg F) greater than the maximum operating temperature and not more than $111 \mathrm{deg} \mathrm{C}$ ( $200 \mathrm{deg} \mathrm{F}$ ) below the maximum no-flow temperature are proposed to reduce the risk of fire in the use of solar heat transfer liquids.

17. KEY WORDS (six to twolve entrios; alphabetical order; capitalize only the first letter of the first key word unless a proper name; separated by semicolons)

Fire prevention; fire tests; flammability; flash point; heat transfer fluids; insulation; leakage; solar collectors; solar energy.
18. AVAILABILITY
[x] Unlimited

For Official Distribution. Do Hot Release to NTIS

Order From Sup. of Doc., U.S. Government Printing Office, Wasinington, DC 20402, SD Stock No. SNÓ03-003-

¿ Order From National Technical Information Service (NTIS), Springfield, VA. 22161

\begin{tabular}{|l|c|}
\hline $\begin{array}{l}\text { 19. SECURITY CLASS } \\
\text { (THIS REPORT) }\end{array}$ & $\begin{array}{c}\text { 21. NO. OF } \\
\text { PRINTED PAGES } \\
\text { UNCLASSIFIED } \mathrm{X}\end{array}$ \\
\hline $\begin{array}{l}\text { 20. SECURITY CLASS } \\
\text { (THIS PAGE) }\end{array}$ & $\begin{array}{c}\text { 22. Price } \\
\$ 4.50\end{array}$ \\
UNCLASSIFIED & \\
\hline
\end{tabular}




$\frac{J}{D}$
$\frac{1}{d}$
$\vec{w}$

1 